Article

\title{
Long-Term Dynamics of Different Surface Water Body Types and Their Possible Driving Factors in China
}

\author{
Bowei Yu ${ }^{1,2}$, Baoshan Cui ${ }^{1,3, *}$, Yongge Zang ${ }^{4}$, Chunsheng Wu ${ }^{5}$, Zhonghe Zhao ${ }^{6,7}$ and Youxiao Wang ${ }^{6,7}$ \\ 1 State Key Joint Laboratory of Environmental Simulation and Pollution Control, School of Environment, \\ Beijing Normal University, Beijing 100875, China; 1132019606@bnu.edu.cn \\ 2 Research and Development Center for Watershed Environmental Eco-Engineering, \\ Advanced Institute of Natural Science, Beijing Normal University at Zhuhai, Zhuhai 519087, China \\ 3 Yellow River Estuary Wetland Ecosystem Observation and Research Station, \\ Ministry of Education, Dongying 257500, China \\ 4 School of Environment, Tsinghua University, Beijing 100084, China; zangyongge@tsinghua.edu.cn \\ 5 Key Laboratory of Ecosystem Network Observation and Modelling, Institute of Geographic Sciences and \\ Natural Resources Research, Chinese Academy of Sciences, Beijing 100101, China; wucs@igsnrr.ac.cn \\ 6 State Key Laboratory of Resources and Environmental Information System, Institute of Geographic Sciences \\ and Natural Resources Research, Chinese Academy of Sciences, Beijing 100101, China; \\ zhaozhh@lreis.ac.cn (Z.Z.); wangyx.19b@igsnrr.ac.cn (Y.W.) \\ 7 College of Resources and Environment, University of Chinese Academy of Sciences, Beijing 100049, China \\ * Correspondence: cuibs@bnu.edu.cn
}

check for updates

Citation: Yu, B.; Cui, B.; Zang, Y.; Wu, C.; Zhao, Z.; Wang, Y. Long-Term Dynamics of Different Surface Water Body Types and Their Possible Driving Factors in China. Remote Sens. 2021, 13, 1154. https://doi.org/ $10.3390 /$ rs13061154

Academic Editor: Frédéric Frappart

Received: 15 February 2021

Accepted: 16 March 2021

Published: 18 March 2021

Publisher's Note: MDPI stays neutral with regard to jurisdictional claims in published maps and institutional affiliations.

Copyright: (c) 2021 by the authors Licensee MDPI, Basel, Switzerland. This article is an open access article distributed under the terms and conditions of the Creative Commons Attribution (CC BY) license (https:/ / creativecommons.org/licenses/by/ $4.0 /)$.

\begin{abstract}
Various surface water bodies, such as rivers, lakes and reservoirs, provide water and essential services to human society. However, the long-term spatiotemporal dynamics of different types of surface water bodies and their possible driving factors over large areas remain very limited. Here, we used unprecedented surface water data layers derived from all available Landsat images and further developed two databases on China's lakes and reservoirs larger than $1 \mathrm{~km}^{2}$ to document and understand the characteristics of changes in different water body types during 2000 to 2019 in China. Our results show that China is dominated by permanent water bodies. The areas of permanent and seasonal water bodies in China increased by $16,631.02 \mathrm{~km}^{2}(16.72 \%)$ and $16,994.95 \mathrm{~km}^{2}(25.14 \%)$, respectively, between 2000 and 2019, with permanent and seasonal water bodies exhibiting divergent spatial variations. Lakes and artificial reservoirs larger than $1 \mathrm{~km}^{2}$, which collectively represent a significant proportion of the permanent water bodies in China, displayed net increases of $6884.52 \mathrm{~km}^{2}$ $(10.71 \%)$ and $4075.13 \mathrm{~km}^{2}$ (36.10\%), respectively, from 2000 to 2019; these increases accounted for $41.40 \%$ and $24.50 \%$, respectively, of the total permanent water body increment. The expanding lakes were mainly distributed on the Tibetan Plateau, whereas the rapidly growing reservoirs were mainly located on the Northeast Plain and Eastern Plain. Statistical analyses indicated that artificial reservoirs were an important factor controlling both permanent and seasonal water body changes in most of provinces. Climate factors, such as precipitation and temperature, were the main influencing factors affecting the changes in different water bodies in the sparsely populated Tibetan Plateau.
\end{abstract}

Keywords: China's surface water; lakes and reservoirs; variation; climate change; human activity; Landsat

\section{Introduction}

Surface water bodies are valuable water resources for humankind. They supply a wide range of services, such as industrial and agricultural production, regional climate regulation, and ecosystem maintenance [1-3]. Surface water bodies play indispensable roles in hydrological and biogeochemical cycles across local, national and global scales [4]. The areas of surface water bodies are highly sensitive to climate and anthropogenic activities; they are therefore indicators of the various contributions of environmental change and human activity $[5,6]$. Variations in surface water bodies are widespread globally due 
to various factors $[7,8]$. For example, climate change has led to the disappearance of Arctic ponds and divergent changes in the extension of water bodies in China and the contiguous United States $[9,10]$. The pond surface area has been reduced in the Italian Alps due to an increased evaporation/precipitation ratio [11]. Changes in glacial lakes in the Third Pole regions are mainly driven by glacier melt and precipitation patterns [12,13]. Additionally, anthropogenically driven changes in surface water resources are increasingly becoming an important concern because of elevated water demands for domestic use, crop irrigation, manufacturing and other uses $[14,15]$. The hydraulic connectivity between groundwater and surface water also presents considerably complicated with the impacts of groundwater pumping, construction and regulation of dams, and improvement of riverbeds [16]. Moreover, severe variations in surface water bodies can lead to floods or droughts, which are very destructive and cause great economic losses and even human casualties (e.g., Australia's millennium drought). Monitoring the dynamics of surface water bodies and understanding their influencing factors can facilitate the sustainable development of water resources and provide multiple benefits for humans [17].

China has one of the largest populations in the world but one of the lowest per-capita amounts of water resources; $18.5 \%$ of the world's population shares only $7.7 \%$ of the global freshwater resources $[18,19]$. Over the past several decades, pronounced climate change and rapid economic and population growth in China have exacerbated regional discrepancies in both water quantity and water quality [20-22]. Due to the tremendous spatial differences in climate and topographical patterns and economic development levels, different surface water body types are heterogeneously distributed in China. Moreover, China has frequently suffered from floods and droughts [23-25]. Understanding the patterns of spatiotemporal change of different types of surface water bodes is important for increasing water sustainability and ensuring water security in China under the conditions of climate change and increasing human activities.

Remote sensing provides a convenient platform for monitoring the long-term changes of surface water bodies. For example, moderate resolution imaging spectroradiometer (MODIS) sensors have been frequently used to monitor surface water changes across largescale regions [26-30]. However, the spatial resolution of MODIS products, 250 or $500 \mathrm{~m}$, is extremely coarse, especially for detecting small variations in small surface water bodies, which are very common across China. Although previous studies have examined changes in surface water bodies using Landsat satellite imagery in China [4,31-33], most involve time-specific comparisons and lack enough data points over time to capture the temporal dynamics of surface water bodies. Due to the strong intra- and interannual variations in surface water bodies in China, such epoch-based studies might miss important information on interannual variations and surface water seasonality. Moreover, several studies have focused only on certain hotspots (e.g., Yangtze River basin, Tibetan Plateau) and specific surface water body types (e.g., lakes, ponds or reservoirs) [34-36].

Several surface water datasets have been generated and used to document changes in specific water bodies, such as the Global Lakes and Wetlands Database (GLWD) [37], the global HydroLAKES database and the Global Reservoir and Dam Database (GRanD) [38,39]. China has also conducted several lake inventories [35,40-42]. However, these global datasets and China's inventories are constructed from satellite images from a specific year or years and capture little of the temporal changes in water bodies; they thus can provide little insight into their causes and consequences. Recently, an unprecedented effort by Pekel et al. [2] produced a global dataset to document changes in surface water bodies at a resolution of $30 \mathrm{~m}$. Although the overall dynamics of water body change have been analysed in China [10,36], there have been only a few regional scale studies in China and more detailed and elaborate analyses of the spatial patterns of changes in different water body types in China remain lacking. Previous studies have aggregated the changes of various types of surface water bodies, thereby masking differences in the patterns of change among them [43]. 
Explicitly considering different types of surface water bodies is essential for understanding the spatiotemporal patterns of water changes at large scales. This is especially true for China because of its vast heterogeneous territories from the Tibetan Plateau to coastal deltas. In addition, China is a global hotpot for dam construction [44]. For example, China constructed more than 80 major dams from 2000 to 2015, most of which are distributed in the southwestern part of the country [45]. Among them, the Three Gorges Dam (TGD) created a giant artificial reservoir of $>1000 \mathrm{~km}^{2}$ since its operation was initiated in 2003 . The Danjiangkou Reservoir, a water source for the South-North Water Transfer project, expanded the surface water area with an increase in dam height. China has also experienced the greatest change in climate in recent decades [46], particularly in the Tibetan Plateau and northwest China. However, few studies have investigated the long-term changes in different types of surface water bodies (e.g., lakes and reservoirs) using high-resolution Landsat images throughout China. Such investigations of surface water body types can provide indispensable insights into the mechanisms of water changes in such a complex context as China. Thus, the objectives of this study were to (1) explore the long-term spatial and temporal variations in different types of surface water bodies in China during the last two decades using the Google Earth Engine (GEE) [47] and (2) assess the relative contributions of climate change and human activities to the changes in different types of surface water bodies.

\section{Materials and Methods}

\subsection{Study Area}

This study includes 23 provinces, five autonomous regions and four municipalities in China, covering about $9.6 \times 10^{6} \mathrm{~km}^{2}$ (Figure 1). It is characterized by tremendous differences in topography. The eastern and northeastern plains of China (i.e., the Eastern Plain and Northeast Plain) consist of fertile lowlands and foothills, and most of China's population is distributed in these provinces. The southern areas of China (i.e., the YunnanGuizhou Plateau) consist of hilly and mountainous terrain, and northwest China (i.e., Xinjiang and the Inner-Mongolian Plateau) are dominated by sunken basins and rolling plateaus. The Tibetan Plateau, the highest and largest plateau in the world, is located in southwestern China and has a much lower population (Figure 1). The climate in China also varies substantially due to its wide coverage and assortment of terrains, as well as the different distances to the sea from different locations. The tremendous differences in latitude, longitude, and altitude cause many variations in annual precipitation and mean temperature within China, which combine to make the climate in China very complex. Given the obvious spatial heterogeneity of geographical environments, climate change and population distribution in China, the space division by province in this study can make it convenient for us to quantify the spatial distribution of different water bodies and their corresponding driving factors, providing more detailed information for surface water resource management at regional scale in China.

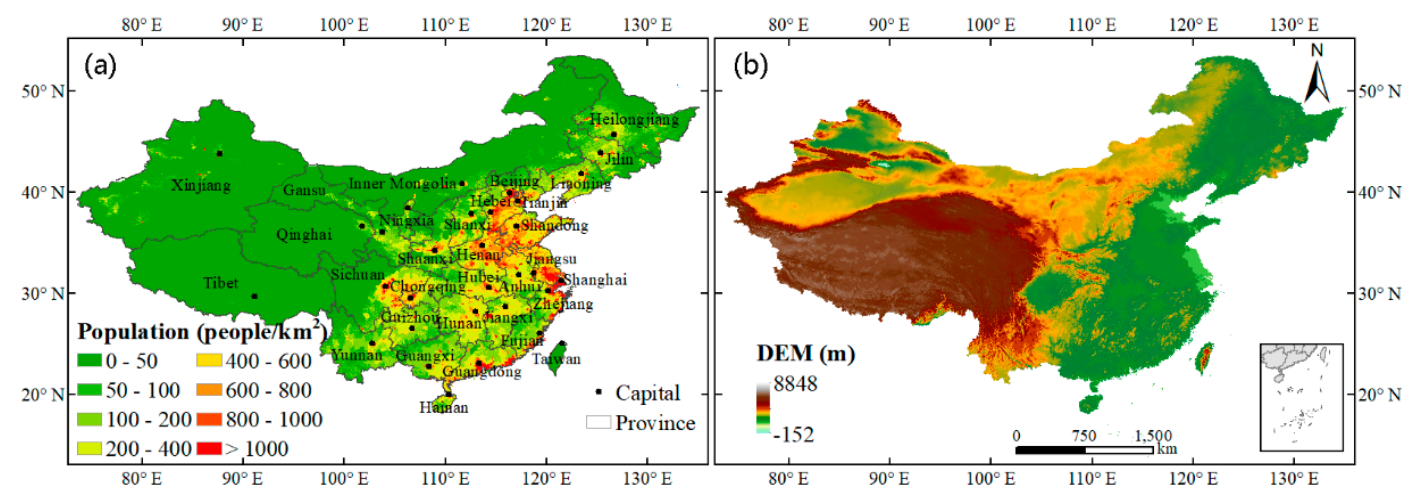

Figure 1. Study area. (a) Map of population density in 2015, administration units and capitals in China, and (b) digital elevation model (DEM) of China. 


\subsection{Data Collection and Processing}

\subsubsection{Multi-Source Remote Sensing Data}

The Global Surface Water Dataset (GSWD), which was published by the European Commission's Joint Research Centre, was used to analyse the spatiotemporal patterns of surface water in our study (https: / / global-surface-water.appspot.com, accessed on 17 August 2020). The GSWD data set was generated using 4,185,439 scenes from Landsat 5, 7, and 8 acquired between 16 March 1984 and 31 December 2019 with a spatial resolution of $30 \mathrm{~m}$. Expert systems, visual analytics and evidential reasoning have been exploited to address challenges in separating water from other surfaces on the global scale over multiple decades. More implementation details of these techniques can be found in Pekel et al. [2]. The resultant maps contain different facets of the spatial and temporal distribution of surface water over the last 36 years. Specifically, the water occurrence, occurrence change intensity, seasonality, recurrence, transitions, maximum water extent, yearly history and monthly history are shown in the dataset. The developers of GSWD have assessed the accuracy of the water maps in terms of errors of omission and commission at the pixel level. Overall, the errors of omission were less than $5 \%$ and commission less than $1 \%$ [2].

We used the water seasonality layer, the maximum water extent layer and the yearly history layer in the present study. The seasonality layer provides information concerning the intra-annual behaviour of water surfaces for a single year (i.e., 1 January 2019 to 31 December 2019) for both permanent and seasonal waters, and the number of months of water is included (Table 1). Permanent water is defined as an area that is covered by water throughout the year, whereas seasonal water refers to an area that is not covered by water in some months $[2,48]$. In general, permanent water is composed of large lakes, reservoirs and major rivers, and seasonal water consists of the edges of permanent water, small ponds and streams, and flooded regions (e.g., rice fields) [10,49]. The maximum water extent layer provides information on all the locations ever detected as water over the 36-year period. Using this information, we obtained lake and reservoir boundaries to examine the changes in permanent and seasonal waters in lakes and reservoirs. The yearly historical layer provides permanent and seasonal water areas for each year from 1984 to 2019. However, there was limited availability of Landsat images for the early period; thus, these images could not completely reflect the annual surface water area, which resulted in large uncertainties in the comparison of surface water changes $[50,51]$. For example, the yearly history dataset omitted most surface water bodies in 1994 in China and failed to detect the major floods in southern China in 1997 to 1998 [10]. Therefore, we selected yearly data after 2000 and examined the temporal changes in different surface water bodies from 2000 to 2019. All calculations of the surface water were performed on the GEE platform.

Table 1. Water seasonality and corresponding months for the presence of water in 2019 in China.

\begin{tabular}{|c|c|c|}
\hline Water Seasonality & Area $\left(10^{3} \mathrm{~km}^{2}\right)$ & Percentage (\%) \\
\hline 1 month of water & 19.97 & 9.95 \\
\hline 2 months of water & 16.87 & 8.41 \\
\hline 3 months of water & 13.23 & 6.59 \\
\hline 4 months of water & 9.78 & 4.88 \\
\hline 5 months of water & 8.08 & 4.02 \\
\hline 6 months of water & 6.48 & 3.23 \\
\hline 7 months of water & 4.90 & 2.44 \\
\hline 8 months of water & 3.17 & 1.58 \\
\hline 9 months of water & 1.46 & 0.73 \\
\hline 10 months of water & 0.52 & 0.26 \\
\hline 11 months of water & 0.11 & 0.05 \\
\hline 12 months of water & 116.09 & 57.85 \\
\hline Total area of water & 200.67 & 100.00 \\
\hline
\end{tabular}

To reduce the uncertainties in precipitation and temperature, we used two climate data products in our study: the $0.5^{\circ}$ gridded climate data from the China Meteorological 
Administration (CMA) version 2.0 (http:/ / data.cma.cn, accessed on 20 August 2020) and the $0.5^{\circ}$ data from the Climatic Research Unit Time Series (CRU TS) version 4.04 (http:/ / www.cru.uea.ac.uk/data, accessed on 23 August 2020). The precipitation and temperature from CMA v2.0 were obtained by using the thin plate spline (TPS) smoothing algorithm of ANUSPLIN software for spatial interpolation based on 2472 national-level meteorological stations in China [52]. The TPS has high interpolation accuracy by the incorporation of parametric linear sub-model, in addition to the independent spline variables; thus, it is more suitable for time series of meteorological data by processing one more surface layer one time [53]. The CRU TS v4.04 climate data were produced using angular distance weighting (ADW) interpolation by the CRU at the University of East Anglia [54]. ADW interpolation can employ a distance weighting function and can make use of any number of weather stations so that stations closest to the grid point of interest carry greater weight; thus, it is better in areas with sparse data [55]. We calculated the annual precipitation (AP, in millimetres) and annual mean temperature (AMT, in degrees Celsius) based on the average of the monthly CMA v2.0 and CRU TS v4.04 datasets in this study.

The MCD12Q1 v6 product (http:/ /LPDAAC.usgs.gov, accessed on 25 August 2020) provides global annual maps of land cover at a spatial resolution of $500 \mathrm{~m}$ for the period from 2001 to 2019. This product was derived using supervised classification of MODIS Terra and Aqua reflectance data and then underwent additional post-processing to further refine specific classes. We selected all cropland area data in the MCD12Q1 v6 product (2001 to 2019), which were based on the International Geosphere-Biosphere Program (IGBP) classification schemes.

\subsubsection{Data on China's Lakes and Reservoirs}

To illustrate the temporal changes in China's lakes and reservoirs, we developed two databases on lakes and reservoirs. Lakes and reservoirs larger than $1 \mathrm{~km}^{2}$, which comprise most of the total lake and reservoir areas, were considered in the present study. Lakes were identified from existing studies [41,42], Open Street Map (OSM, https: / /www.openstreetmap.org, accessed on 27 August 2020) and Google Earth. Reservoirs were identified from GRanD v1.3 (http: / / www.globaldamwatch.org, accessed on 27 August 2020), National Energy Administration in China (NEAC, http:/ /www.dam.com.cn, accessed on 27 August 2020), OSM and Google Earth. For our analysis, it was important that all of the identified lakes and reservoirs have accurate geolocation information (latitude and longitude); thus, we were able to determine the boundaries of the lakes and reservoirs based on the maximum water extent layer from the GSWD data set. Accordingly, we checked the geolocations of each lake and reservoir and made corrections in Google Earth, as most lakes and reservoirs had inaccurate geolocation information. For example, the GRanD v1.3 dataset is widely used and provides near comprehensive information about global reservoirs and associated dams. It contains a total of 923 reservoirs in China, but 51 to $55 \%$ of reservoirs in the dataset have inaccurate geolocation information [10]. In addition, it is important that lakes should not be confused with reservoirs; a reservoir is identified on the basis of whether the water body has a corresponding dam. In general, in existing studies, some lakes are actually reservoirs, and vice versa.

In the present study, a total of 2655 lakes and 2618 reservoirs with areas greater than $>1 \mathrm{~km}^{2}$ were identified in China. According to previous studies, these lakes and reservoirs can be categorized into three classes: small (1 to $\left.10 \mathrm{~km}^{2}\right)$, medium (10 to $50 \mathrm{~km}^{2}$ ) and large lakes/reservoirs $\left(>50 \mathrm{~km}^{2}\right)[35,56]$. The lake distribution was highly heterogeneous and poorly matched with human demand across China (Figure 2). Small and medium lakes were mainly distributed in Inner Mongolia, Northeast China and the middle and lower reaches of the Yangtze River basin, whereas large lakes were mainly distributed on the Tibetan Plateau. The reservoirs were mainly located in Central and East China, which was highly consistent with the population distribution (Figure 2). Moreover, in terms of number, small lakes/reservoirs were most abundant, whereas in terms of area, large 
lakes/reservoirs were the largest, indicating that large lakes/reservoirs comprised most of the total lake/reservoir area.
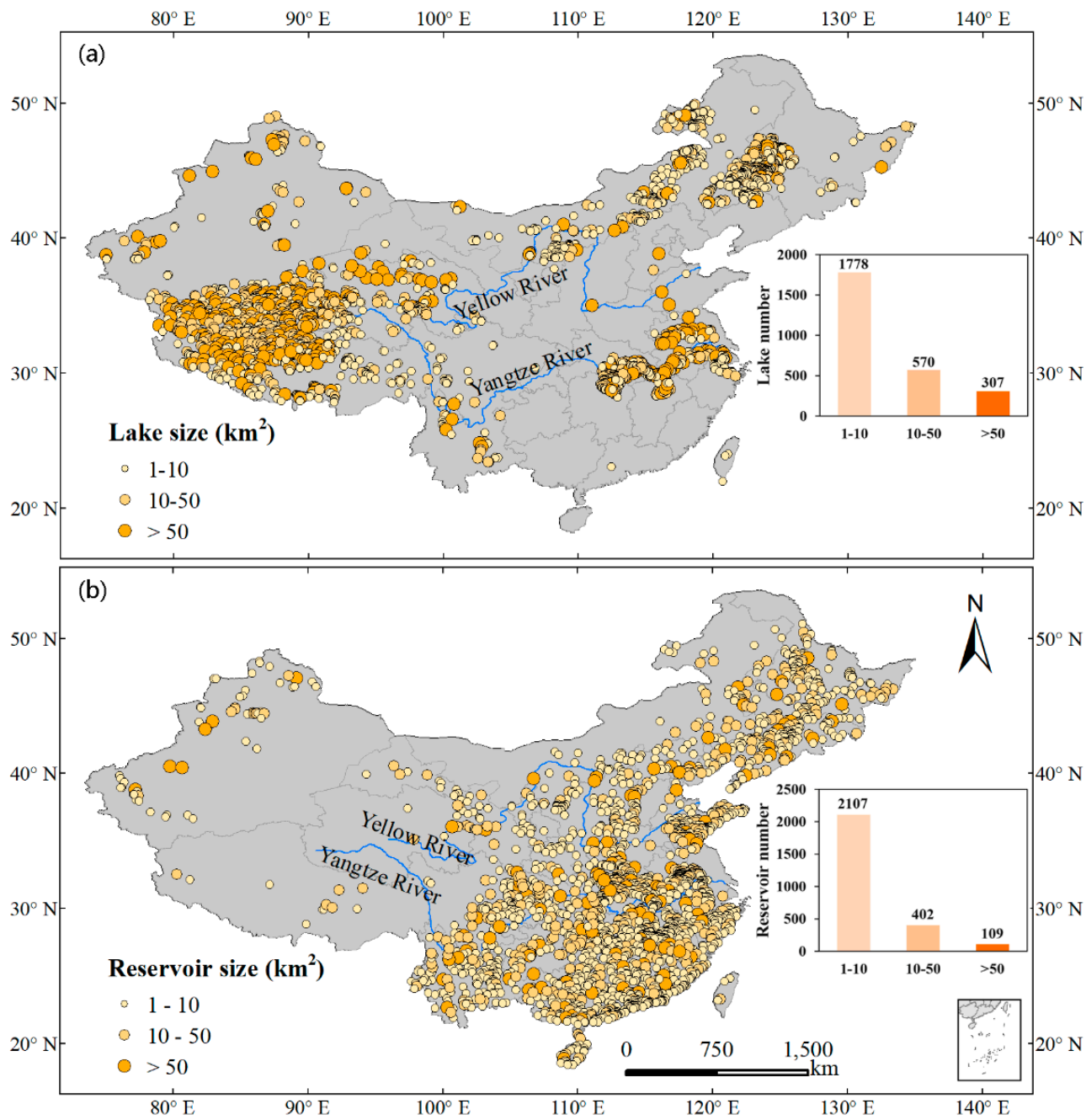

Figure 2. Distribution of (a) lakes and (b) reservoirs with area greater than $1 \mathrm{~km}^{2}$ in China.

\subsection{Statistical Analyses}

\subsubsection{Mann-Kendall Test and Median Trend Analysis}

The nonparametric Mann-Kendall (MK) test was used to detect significant changes in our long-term permanent and seasonal water bodies and the associated driver variables at the provincial scale $[57,58]$. The results were interpreted by using the $\mathrm{z}$-score metric, in which the sign indicates the direction and the value indicates the magnitude of the trend. In addition, the MK test was applied to each lake and reservoir considered in our study. Where a significant trend was identified by the MK test, we performed the Theil-Sen slope estimator to calculate the slope to represent change $[59,60]$. This method is much less sensitive to outliers than simple linear regression and calculates the median slopes of lines crossing all possible pairs of points in the dataset [61]. It has been widely used to explore trend magnitudes in climate and hydrology time series datasets and is usually performed with the MK test [62]. In our study, the Theil-Sen slope was used for all the variables of interest (i.e., permanent and seasonal water bodies, lakes and reservoirs, and driving factors) for which a trend was identified by the MK test. The formula of the Theil-Sen median trend $Q$ is as follows:

$$
Q=\operatorname{median} \frac{X_{i}-X_{j}}{t_{i}-t_{j}}
$$


where $X_{i}$ and $X_{j}$ are the data values at times $t_{i}$ and $t_{j}(i>j)$, respectively.

\subsubsection{Correlation and Linear Analysis}

The driving factors of changes in both permanent and seasonal water bodies were analysed at the provincial scale. We carried out a two-step analysis. First, the correlation of each climate and human factor with the areas of permanent and seasonal water bodies at the provincial scale was quantified. Then, we conducted linear model fitting and analysis of variance (ANOVA) to quantify the relative contribution of each of the influencing factors to the changes in the areas of permanent and seasonal water bodies. All statistical analyses were performed using $\mathrm{R}$ version 3.6.1 [63].

\section{Results}

\subsection{Changes in Surface Water Bodies in China}

At the national scale, the total surface water area in 2019 in China was $0.201 \times 10^{6} \mathrm{~km}^{2}$, of which the areas of permanent and seasonal water were $0.116 \times 10^{6} \mathrm{~km}^{2}$ and $0.085 \times 10^{6} \mathrm{~km}^{2}$, respectively (Table 1 and Figure 3). The results indicate that China is dominated by permanent water bodies. However, both permanent and seasonal water bodies at the provincial level clearly show heterogeneous spatial distributions across China. The permanent water was mainly distributed between 80 to $90^{\circ} \mathrm{E}$ and 110 to $120^{\circ} \mathrm{E}$ longitude and 27 to $37^{\circ} \mathrm{N}$ latitude, whereas the seasonal water was mainly distributed between 110 to $125^{\circ} \mathrm{E}$ longitude and 27 to $47^{\circ} \mathrm{N}$ latitude. The distribution of surface water also varied greatly at the provincial scale (Figures 3 and 4). The largest area of permanent water bodies was in Tibet, with an area of $33,196.28 \mathrm{~km}^{2}$, whereas the largest area of seasonal water bodies was in Heilongjiang, with an area of $10,195.94 \mathrm{~km}^{2}$. The ratio of permanent water to seasonal water in Tibet was 4.32, whereas the corresponding ratio for Shanxi was only 0.51. In total, thirteen provinces had a ratio greater than 1 , indicating that permanent water bodies are the main source of water resources in these provinces. In general, permanent water bodies consisted mainly of lakes and reservoirs with areas greater than $1 \mathrm{~km}^{2}$. For example, the lake area was $29,646.76 \mathrm{~km}^{2}$, accounting for $89.31 \%$ of the total permanent water bodies in Tibet, and the reservoir area covered $90.55 \%$ of the total permanent water bodies in Chongqing (Figure 4).

Both permanent and seasonal water bodies underwent apparent increases throughout China in the last twenty years (Figure 5). Permanent water increased by $16.72 \%$, from $0.099 \times 10^{6} \mathrm{~km}^{2}$ in 2000 to $0.116 \times 10^{6} \mathrm{~km}^{2}$ in 2019 , and seasonal water increased by $25.14 \%$, from $0.068 \times 10^{6} \mathrm{~km}^{2}$ in 2000 to $0.085 \times 10^{6} \mathrm{~km}^{2}$ in 2019 . The trends of permanent and seasonal water bodies over 2000 to 2019 were surface water area gains of $917.01 \mathrm{~km}^{2} \mathrm{yr}^{-1}$ and $491.33 \mathrm{~km}^{2} \mathrm{yr}^{-1}$, respectively. In general, the area of lakes and reservoirs increased with increasing permanent water area between 2000 and 2019 (Figure 5).

Provincially heterogeneous variations in surface water bodies during 2000 to 2019 in China were clear (Figures 6 and 7). The interannual trends of both permanent and seasonal water bodies in China during 2000 to 2019 by provinces are presented in Figure 6, in which the slope and $\mathrm{P}$ values are the linear rate of change and the level of significance, respectively. For permanent water, twenty-two provinces presented significantly increasing trends, ranging from $0.45 \mathrm{~km}^{2} \mathrm{yr}^{-1}$ in Shanghai to $190.52 \mathrm{~km}^{2} \mathrm{yr}^{-1}$ in Tibet. Qinghai ranked second in its increase in permanent water $\left(155.24 \mathrm{~km}^{2} \mathrm{yr}^{-1}\right)$. However, Tianjin displayed a significant decreasing trend over the last twenty years $\left(-4.19 \mathrm{~km}^{2} \mathrm{yr}^{-1}\right)$. For seasonal water, six provinces showed significantly increasing trends, ranging from $14.34 \mathrm{~km}^{2} \mathrm{yr}^{-1}$ in Hebei to $206.25 \mathrm{~km}^{2} \mathrm{yr}^{-1}$ in Xinjiang. Tibet ranked second in its increase in seasonal water. In contrast, three provinces displayed significant decreasing trends in seasonal water, ranging from $-2.84 \mathrm{~km}^{2} \mathrm{yr}^{-1}$ in Shanghai to $-42.56 \mathrm{~km}^{2} \mathrm{yr}^{-1}$ in Shandong (Figure 6). Furthermore, we calculated the area increase/decrease in both permanent and seasonal waters between 2000 and 2019 at the provincial scale (Figure 7). Twenty-seven provinces revealed apparent increases in permanent water from 2000 to 2019, with a percentage increase ranging from $0.67 \%$ in Jiangxi to $160.37 \%$ in Ningxia. The five provinces with the 
largest increases in permanent water were Tibet $(30.62 \%$, i.e., net change area/total net change area), Qinghai (17.42\%), Xinjiang (10.05\%), Shandong (6.54\%) and Hubei (6.03\%). Five provinces exhibited decreases in permanent water, ranging from $-10.51 \mathrm{~km}^{2}$ in Taiwan to $-313.49 \mathrm{~km}^{2}$ in Mongolia. In regard to the net seasonal water change, twenty-two provinces showed increases, with a percentage increase ranging from $4.64 \%$ in Mongolia to $121.48 \%$ in Guizhou. Heilongjiang experienced the largest seasonal water gain $(31.06 \%)$, followed by Xinjiang $(23.77 \%)$ and Tibet $(17.91 \%)$, whereas Hubei experienced the largest loss $(-4.24 \%)$, followed by Shandong $(-1.91 \%)$ and Henan $(-1.31 \%)$ (Figure 7$)$.
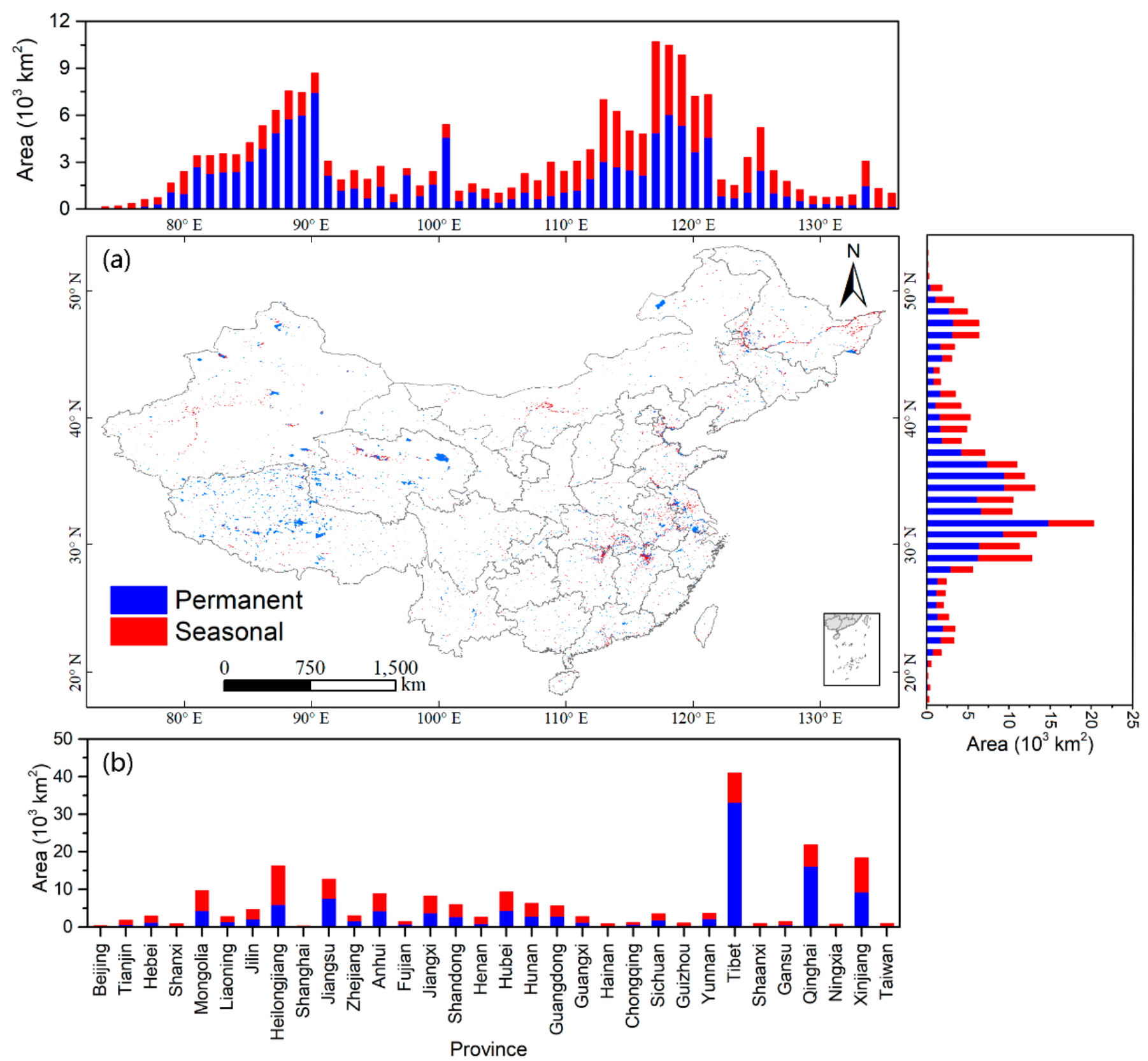

Figure 3. Spatial distribution of surface water bodies in 2019 in China. (a) Spatial distribution of permanent and seasonal water areas based on longitude and latitude, and (b) permanent and seasonal water areas by province. 

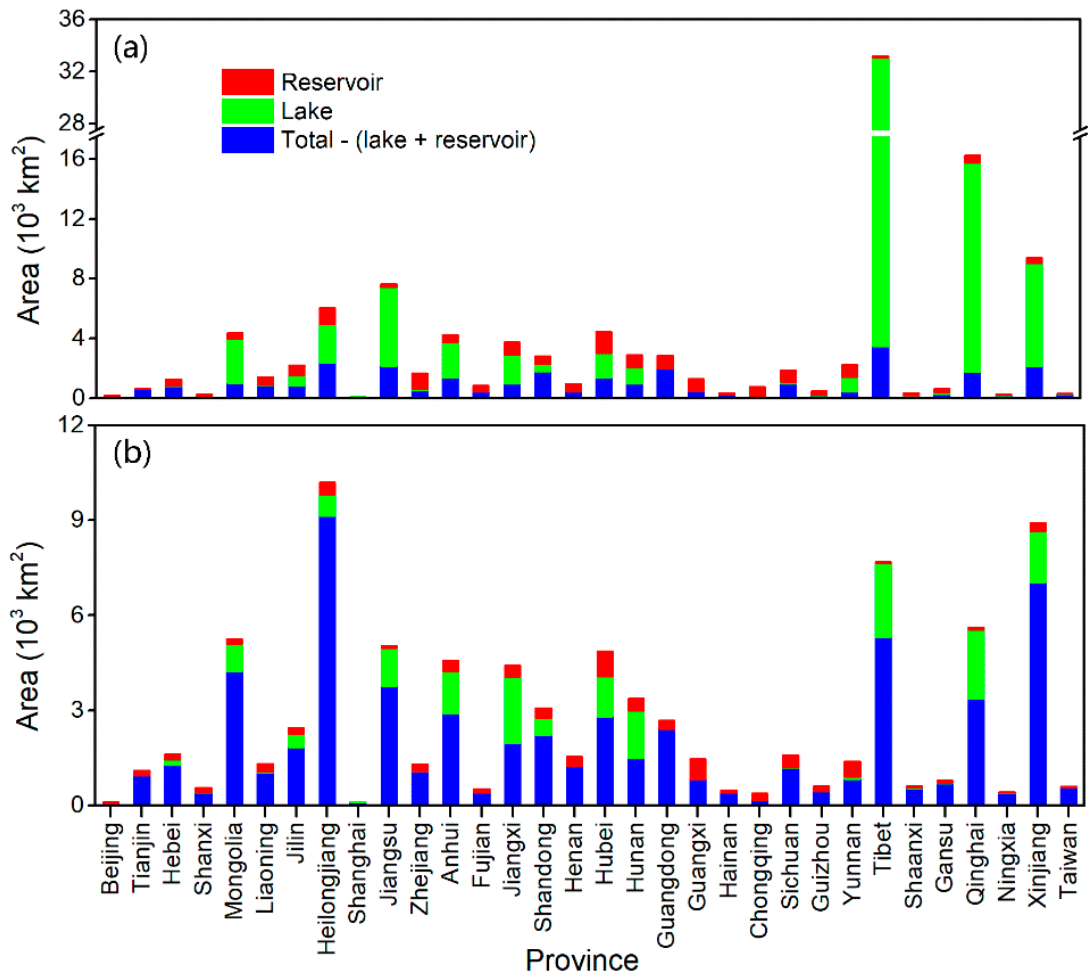

Figure 4. Area of different surface water bodies at the provincial scale in 2019. (a) Permanent water, and $(\mathbf{b})$ seasonal water.
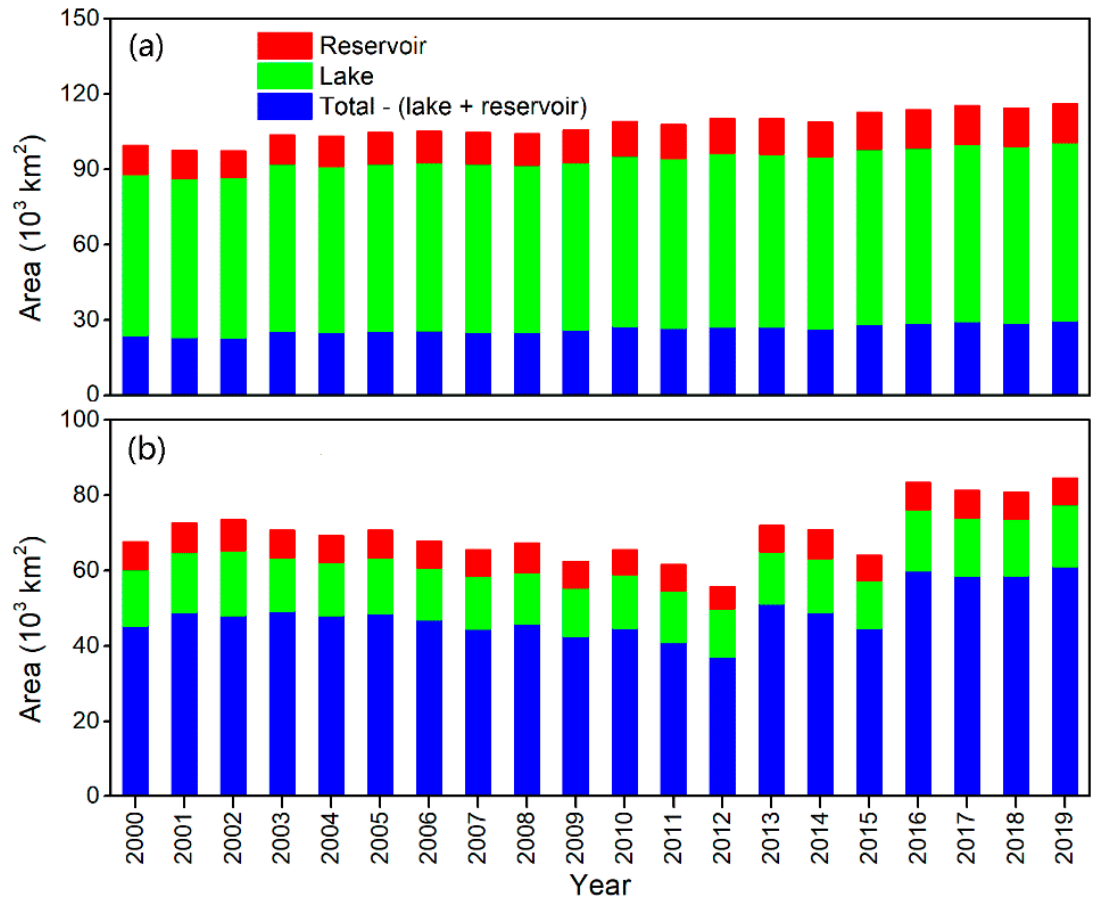

Figure 5. Area of different surface water bodies in China during 2000 to 2019. (a) Permanent water, and (b) seasonal water. 


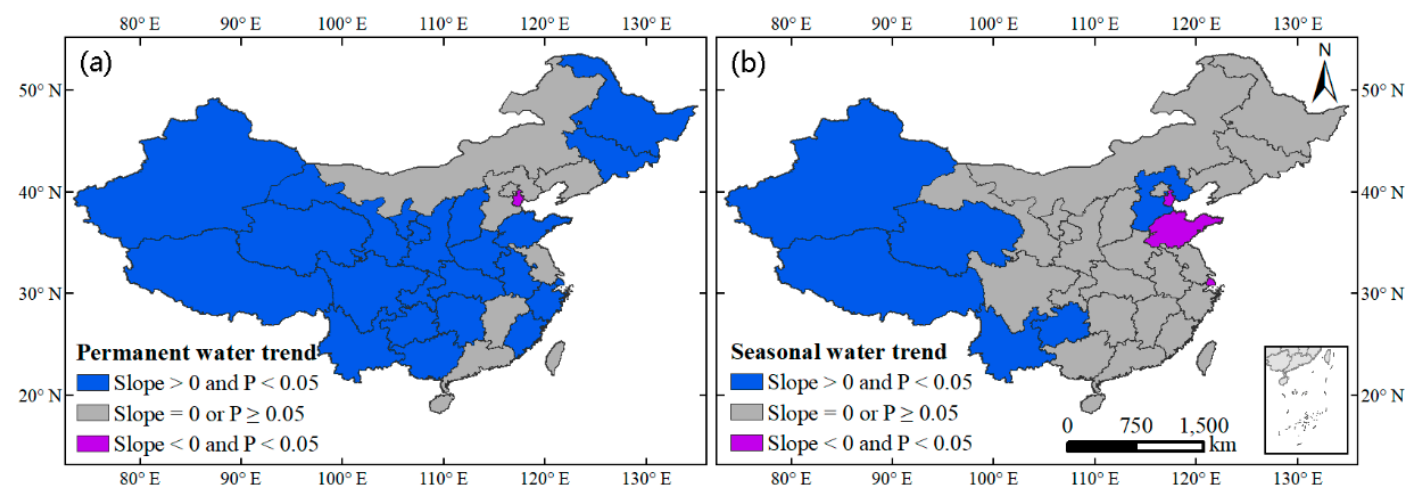

Figure 6. Map of interannual trends in surface water bodies during 2000-2019. (a) Permanent water, and (b) seasonal water.
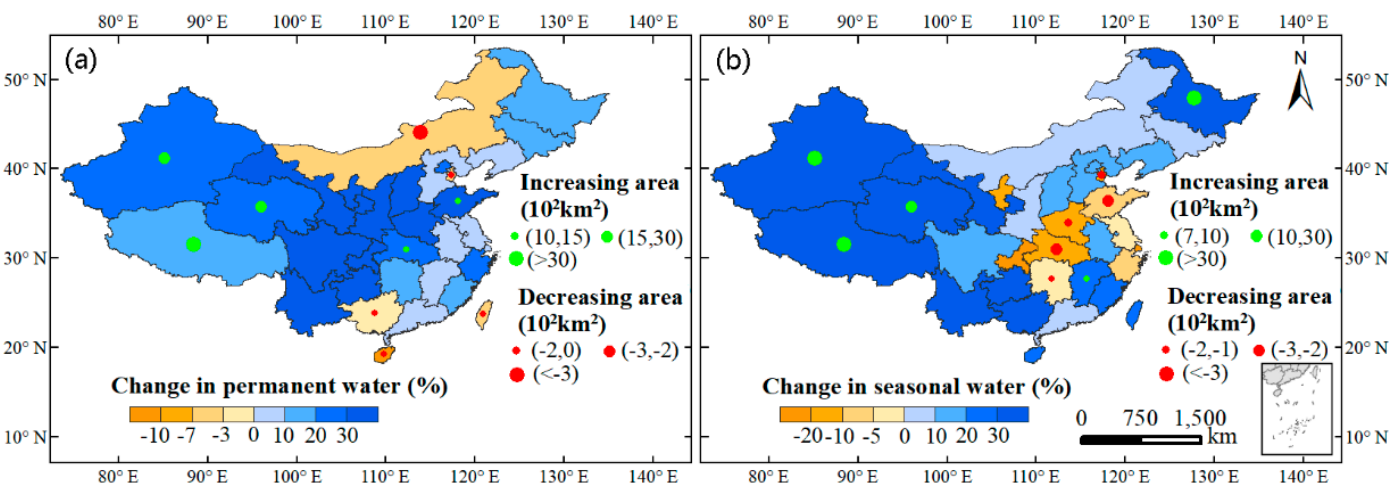

Figure 7. Net changes in surface water bodies during 2000 to 2019. (a) Permanent water, and (b) seasonal water. Only the top five provinces in terms of body area increase or decrease are marked.

\subsection{Changes in Lakes}

The total permanent and seasonal water areas of all lakes $>1 \mathrm{~km}^{2}$ in all of China increased by $10.71 \%$, from $64,287.97 \mathrm{~km}^{2}$ in 2000 to $71,172.49 \mathrm{~km}^{2}$ in 2019 , and by $9.16 \%$, from $15,068.98 \mathrm{~km}^{2}$ in 2000 to $16,449.56 \mathrm{~km}^{2}$ in 2019 , respectively. The spatial patterns of lake area trends showed that expanding lakes with permanent water bodies were mainly distributed on the Tibetan Plateau (52.65\%), in Northeast China (13.66\%) and in the middle and lower reaches of the Yangtze River basin $(17.41 \%)$, whereas rapidly growing lakes with seasonal water bodies were mostly found on the Tibetan Plateau (70.64\%) (Figure 8). The shrinking lakes with permanent water bodies had the same distribution as that of expanding lakes. In contrast, shrinking lakes with seasonal water bodies were mainly found in Northeast China (18.17\%) and the middle and lower reaches of the Yangtze River basin (42.68\%). Lake size analysis showed different spatial patterns of evolution (Figures 1 and 8 ). For the permanent water bodies, expanding and shrinking lakes of small sizes $\left(1\right.$ to $\left.10 \mathrm{~km}^{2}\right)$ and medium sizes $\left(10\right.$ to $50 \mathrm{~km}^{2}$ ) were mainly distributed on the Tibetan Plateau, in Northeast China and in the middle and lower reaches of the Yangtze River basin, whereas large lakes $\left(>50 \mathrm{~km}^{2}\right)$ were mainly located on the Tibetan Plateau and underwent rapid change. Among the seasonal water bodies, medium and large expanding lakes were mainly distributed on the Tibetan Plateau, whereas shrinking lakes were mainly found in the middle and lower reaches of the Yangtze River basin. 


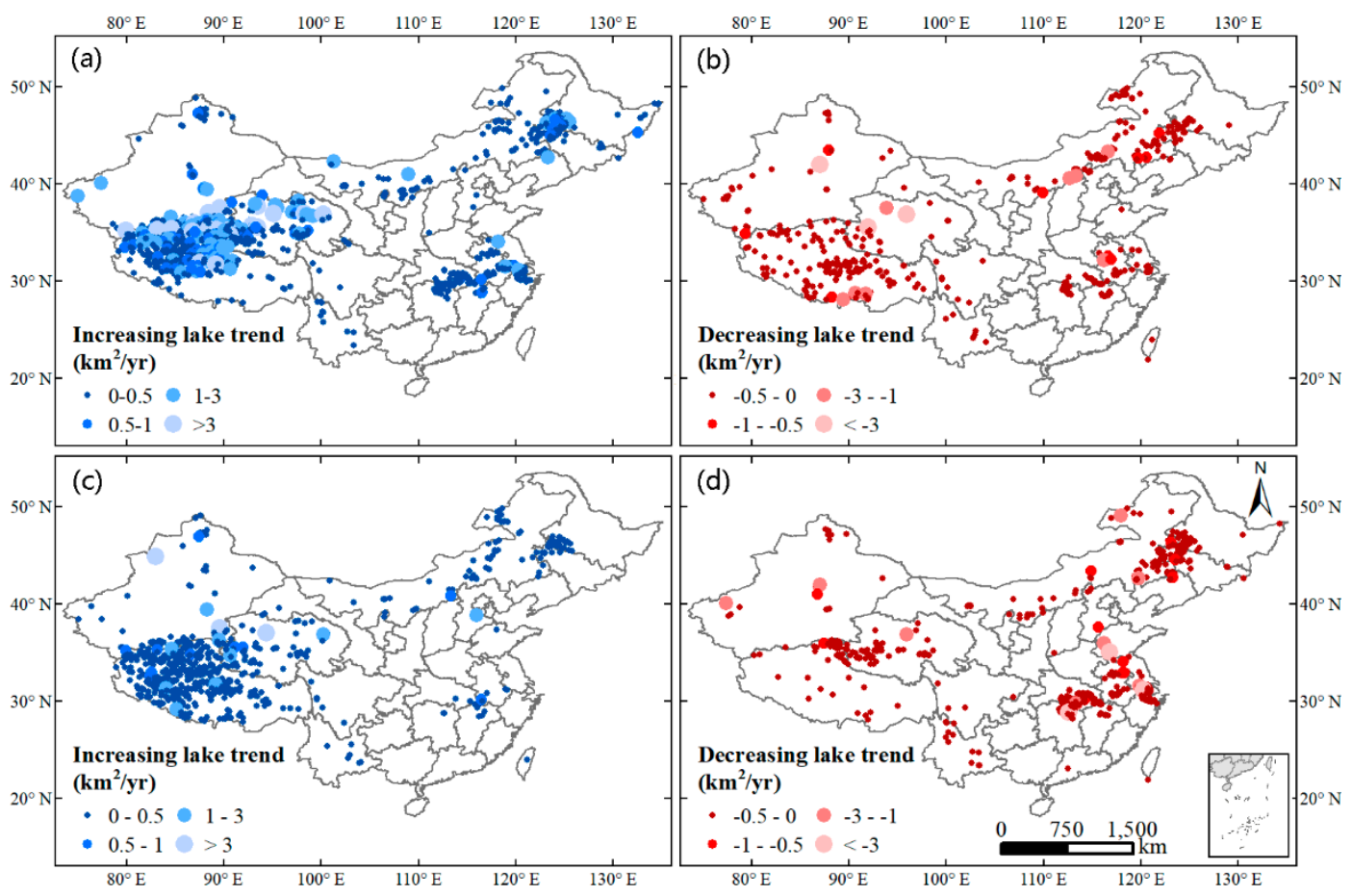

Figure 8. Map of interannual trends in surface water bodies for lakes $>1 \mathrm{~km}^{2}$. (a) Lakes with increased permanent water bodies, (b) lakes with decreased permanent water bodies, (c) lakes with increased seasonal water bodies, and (d) lakes with decreased seasonal water bodies. Only lakes with linear trends with $p<0.1$ are shown.

The changes in lakes with statistically significant trends for 2000 to 2019 are shown in Table 2. There were 1149 and 671 lakes presenting significantly expanding trends for permanent and seasonal water bodies, respectively. Specifically, expanding lakes with permanent water bodies increased by $21.56 \%$, from $36,917.96 \mathrm{~km}^{2}$ in 2000 to $44,878.41 \mathrm{~km}^{2}$ in 2019 , and those with seasonal water bodies increased by $109.20 \%$, from $1616.33 \mathrm{~km}^{2}$ in 2000 to $3381.36 \mathrm{~km}^{2}$ in 2019. In general, the number and area of shrinking lakes were less than those of expanding lakes. A total of 437 and 567 lakes displayed shrinkage for permanent and seasonal water bodies, respectively (Table 2).

Table 2. Statistically significant changes in the areas of all lakes $>1 \mathrm{~km}^{2}$ in China between 2000 and 2019 .

\begin{tabular}{|c|c|c|c|c|c|c|}
\hline Lake Class & $\begin{array}{l}\text { Lake Size } \\
\left(\mathbf{k m}^{2}\right)\end{array}$ & $\begin{array}{c}\text { Lake } \\
\text { Number }\end{array}$ & $\begin{array}{c}\text { Lake Area } \\
\left(\mathrm{km}^{2}\right) \text { in } \\
2000\end{array}$ & $\begin{array}{c}\text { Lake Area } \\
\left(\mathrm{km}^{2}\right) \text { in } \\
2019\end{array}$ & $\begin{array}{c}\text { Change } \\
\text { during } \\
2000-2019 \\
\left(\mathrm{~km}^{2}\right)\end{array}$ & $\begin{array}{c}\text { Change } \\
\text { during } \\
2000-2019 \\
(\%)\end{array}$ \\
\hline \multirow{4}{*}{$\begin{array}{l}\text { Permanent } \\
\text { lakes with } \\
\text { increase }\end{array}$} & $1-10$ & 655 & 970.60 & 1516.97 & 546.37 & 56.29 \\
\hline & $10-50$ & 308 & 3354.34 & 4809.86 & 1455.53 & 43.39 \\
\hline & $>50$ & 186 & $32,593.02$ & $38,551.59$ & 5958.56 & 18.28 \\
\hline & All & 1149 & $36,917.96$ & $44,878.41$ & 7960.46 & 21.56 \\
\hline \multirow{4}{*}{$\begin{array}{l}\text { Permanent } \\
\text { lakes with } \\
\text { decrease }\end{array}$} & $1-10$ & 318 & 682.93 & 493.54 & -189.38 & -27.73 \\
\hline & $10-50$ & 79 & 1171.63 & 1000.59 & -171.04 & -14.60 \\
\hline & $>50$ & 40 & 6228.62 & 5741.81 & -486.80 & -7.82 \\
\hline & All & 437 & 8083.17 & 7235.95 & -847.22 & -10.48 \\
\hline \multirow{4}{*}{$\begin{array}{l}\text { Seasonal } \\
\text { lakes with } \\
\text { increase }\end{array}$} & $1-10$ & 408 & 141.95 & 316.52 & 174.57 & 122.98 \\
\hline & $10-50$ & 157 & 336.12 & 579.59 & 243.48 & 72.44 \\
\hline & $>50$ & 106 & 1138.27 & 2485.24 & 1346.98 & 118.34 \\
\hline & All & 671 & 1616.33 & 3381.36 & 1765.03 & 109.20 \\
\hline \multirow{4}{*}{$\begin{array}{l}\text { Seasonal } \\
\text { lakes with } \\
\text { decrease }\end{array}$} & $1-10$ & 382 & 491.29 & 265.32 & -225.97 & -45.99 \\
\hline & $10-50$ & 127 & 810.65 & 501.71 & -308.94 & -38.11 \\
\hline & $>50$ & 58 & 4008.26 & 3133.87 & -874.38 & -21.81 \\
\hline & All & 567 & 5310.20 & 3900.91 & -1409.29 & -26.54 \\
\hline
\end{tabular}




\subsection{Changes in Reservoirs}

The total permanent water area of all reservoirs $>1 \mathrm{~km}^{2}$ in China increased by $36.10 \%$, from $11,287.51 \mathrm{~km}^{2}$ in 2000 to $15,362.63 \mathrm{~km}^{2}$ in 2019 , whereas the seasonal water area slightly decreased by $1.06 \%$, decreasing from $7204.52 \mathrm{~km}^{2}$ in 2000 to $7128.06 \mathrm{~km}^{2}$ in 2019 . For reservoirs with permanent water, the number of significantly expanding reservoirs was obviously greater than that of significantly shrinking reservoirs (Figure 9). In contrast, there were more significantly shrinking reservoirs than significantly expanding reservoirs among seasonal water bodies. Expanding reservoirs with permanent water bodies were mainly distributed in Hubei, followed by Sichuan, Hunan and Heilongjiang, whereas expanding reservoirs with seasonal water bodies were mostly found in Yunnan, Sichuan and Xinjiang. The shrinking reservoirs with permanent and seasonal water bodies were mainly located in Shandong, Guangdong, Mongolia, Hubei and Henan. Reservoir size analysis showed that expanding permanent reservoirs of small $\left(1\right.$ to $\left.10 \mathrm{~km}^{2}\right)$ and large size $\left(>50 \mathrm{~km}^{2}\right)$ were mainly distributed in Hubei and Sichuan, whereas those of medium size (10 to $\left.50 \mathrm{~km}^{2}\right)$ were distributed in Sichuan and Hunan (Figures 2 and 9). Shrinking seasonal reservoirs of small and medium sizes were mainly located in Hubei and Shandong, whereas those of large size were located in Hubei and Henan.
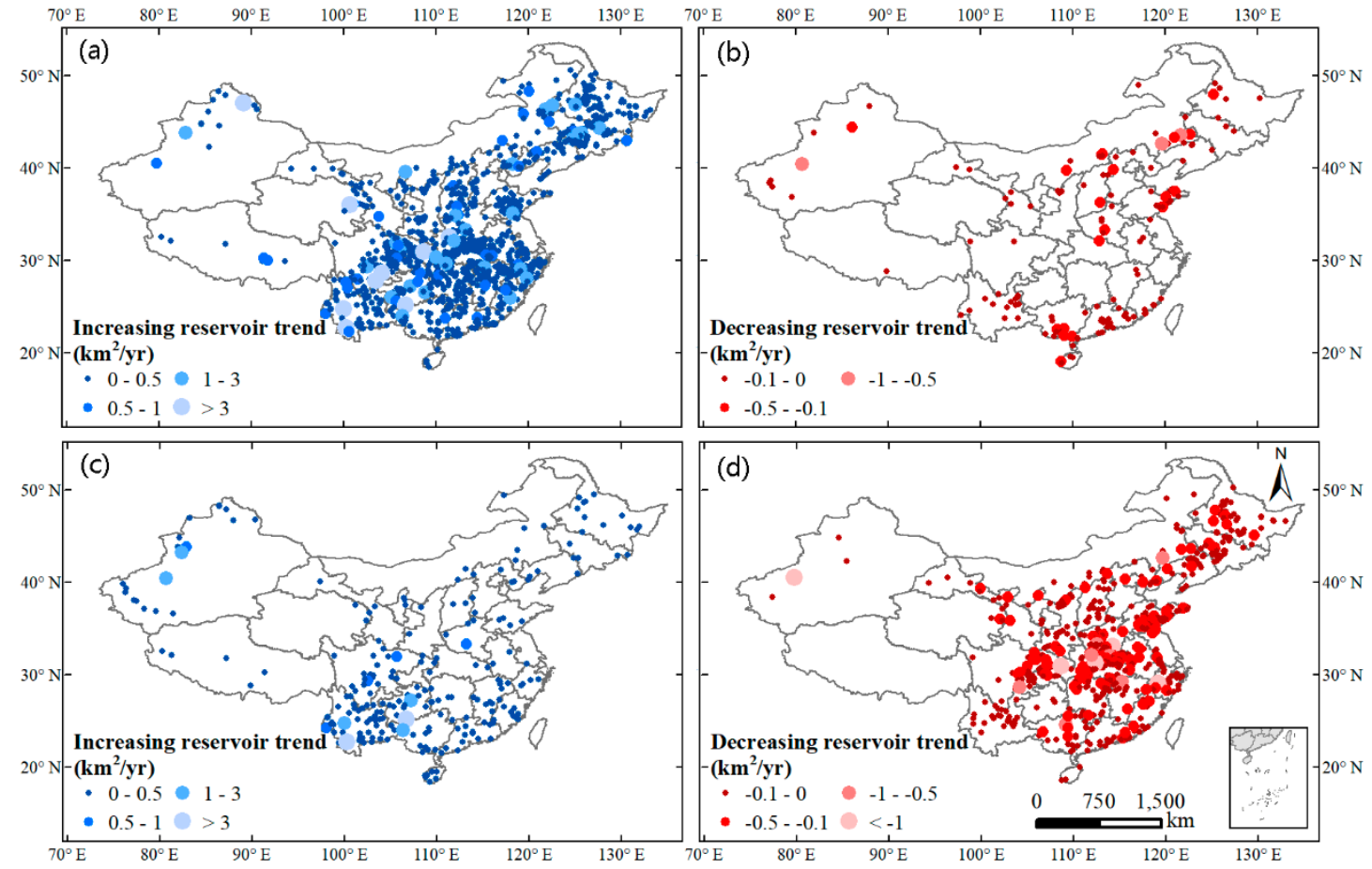

Figure 9. Map of interannual trends in surface water bodies for reservoirs $>1 \mathrm{~km}^{2}$. (a) Reservoirs with increased permanent water bodies, (b) reservoirs with decreased permanent water bodies, (c) reservoirs with increased seasonal water bodies, and (d) reservoirs with decreased seasonal water bodies. Only reservoirs with linear trends with $p<0.1$ are shown.

A total of 1132 and 240 reservoirs showed significant increases in permanent and seasonal water bodies, respectively, accounting for $43.24 \%$ and $9.17 \%$, respectively, of the total number of reservoirs $>1 \mathrm{~km}^{2}$ (Table 3). Reservoir permanent water increased by $67.17 \%$, from $5819.42 \mathrm{~km}^{2}$ in 2000 to $9728.24 \mathrm{~km}^{2}$ in 2019 , and reservoir seasonal water increased by $173.47 \%$, from $416.85 \mathrm{~km}^{2}$ in 2000 to $1139.99 \mathrm{~km}^{2}$ in 2019 . The area of reservoirs with seasonally reduced water bodies $\left(-1128.36 \mathrm{~km}^{2}\right)$ was much higher than that of reservoirs with permanently reduced water bodies $\left(-165.82 \mathrm{~km}^{2}\right)$ over 2000 to 2019 . 
Table 3. Statistically significant changes in the areas of all reservoirs $>1 \mathrm{~km}^{2}$ in China between 2000 and 2019

\begin{tabular}{|c|c|c|c|c|c|c|}
\hline $\begin{array}{l}\text { Reservoir } \\
\text { Class }\end{array}$ & $\begin{array}{l}\text { Reservoir } \\
\text { Size }\left(\mathrm{km}^{2}\right)\end{array}$ & $\begin{array}{c}\text { Reservoir } \\
\text { Number }\end{array}$ & $\begin{array}{c}\text { Reservoir } \\
\text { Area }\left(\mathbf{k m}^{2}\right) \\
\text { in } 2000\end{array}$ & $\begin{array}{c}\text { Reservoir } \\
\text { Area }\left(\mathbf{k m}^{2}\right) \\
\text { in } 2019\end{array}$ & $\begin{array}{c}\text { Change } \\
\text { during } \\
2000-2019 \\
\left(\mathrm{~km}^{2}\right)\end{array}$ & $\begin{array}{c}\text { Change } \\
\text { during } \\
2000-2019 \\
(\%)\end{array}$ \\
\hline \multirow{4}{*}{$\begin{array}{l}\text { Permanent } \\
\text { reservoirs } \\
\text { with } \\
\text { increase }\end{array}$} & $1-10$ & 850 & 686.47 & 1316.57 & 630.11 & 91.79 \\
\hline & $10-50$ & 220 & 1492.54 & 2755.76 & 1263.21 & 84.63 \\
\hline & $>50$ & 62 & 3640.41 & 5655.90 & 2015.49 & 55.36 \\
\hline & All & 1132 & 5819.42 & 9728.24 & 3908.81 & 67.17 \\
\hline \multirow{4}{*}{$\begin{array}{c}\text { Permanent } \\
\text { reservoirs } \\
\text { with } \\
\text { decrease }\end{array}$} & $1-10$ & 129 & 211.51 & 147.74 & -63.78 & -30.15 \\
\hline & $10-50$ & 18 & 173.35 & 116.32 & -57.03 & -32.90 \\
\hline & $>50$ & 4 & 199.63 & 154.62 & -45.01 & -22.55 \\
\hline & All & 151 & 584.50 & 418.67 & -165.82 & -28.37 \\
\hline \multirow{4}{*}{$\begin{array}{l}\text { Seasonal } \\
\text { reservoirs } \\
\text { with } \\
\text { increase }\end{array}$} & $1-10$ & 186 & 103.43 & 236.94 & 133.51 & 129.08 \\
\hline & $10-50$ & 39 & 104.80 & 260.04 & 155.24 & 148.13 \\
\hline & $>50$ & 15 & 208.62 & 643.00 & 434.38 & 208.22 \\
\hline & All & 240 & 416.85 & 1139.99 & 723.13 & 173.47 \\
\hline \multirow{4}{*}{$\begin{array}{l}\text { Seasonal } \\
\text { reservoirs } \\
\text { with } \\
\text { decrease }\end{array}$} & $1-10$ & 582 & 691.08 & 421.36 & -269.71 & -39.03 \\
\hline & $10-50$ & 130 & 912.34 & 559.37 & -352.97 & -38.69 \\
\hline & $>50$ & 32 & 1249.30 & 743.62 & -505.68 & -40.48 \\
\hline & All & 744 & 2852.72 & 1724.36 & -1128.36 & -39.55 \\
\hline
\end{tabular}

\subsection{Factors Influencing Surface Water Area}

We examined the effects of climate and human activities on permanent and seasonal water areas to explore the potential factors driving change. In the present study, we used $\mathrm{AP}$ and AMT as measures of climate and reservoirs and cropland as indicators of human activity. The interannual trends of different influencing factors (AP, AMT and cropland) at the provincial scale are shown in Figure 10, in which the slope and $\mathrm{P}$ values are the linear rate of change and the level of significance, respectively. In the past twenty years, AP significantly increased in the northwest and northeast China, and AMT significantly increased in the southwest and southeast China. Climate factors in other provinces fluctuated but had no obvious overall increasing or decreasing trend. For cropland, twelve provinces showed significant increases, whereas fifteen provinces showed significant decreases in China. In order to examine the new land use in these areas of "cropland decrease" in fifteen provinces, we collected land use/land cover data for the years 2000 and 2015 with $1 \mathrm{~km}$ spatial resolution from the Resource and Environment Data Cloud Platform of the Chinese Academy of Sciences (http:/ / www.resdc.cn, accessed on 10 September 2020) and performed conversion matrix analysis. The results show that cropland was mainly converted into urban land (Table 4), which indicates that the new land use in the areas with "cropland decrease" are most likely to be urban lands.

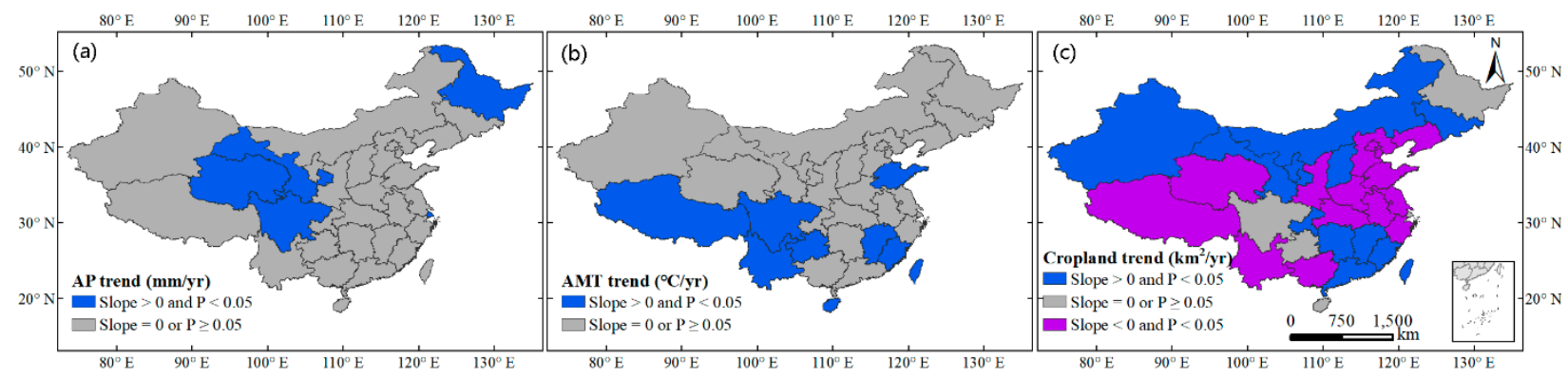

Figure 10. Interannual trends in (a) precipitation, (b) temperature and (c) cropland at the provincial scale in China from 2000 to 2019. 
Table 4. Land use/land cover type transfer matrix from 2000 to 2015 in fifteen provinces with reduced cropland.

\begin{tabular}{|c|c|c|c|c|c|c|c|c|}
\hline \multirow{2}{*}{\multicolumn{2}{|c|}{$\begin{array}{c}\text { Land Use/Land Cover } \\
\text { Types }\end{array}$}} & \multicolumn{7}{|c|}{$2015\left(\mathrm{~km}^{2}\right)$} \\
\hline & & Cropland & Forest & Grassland & Wetland & Urban & $\begin{array}{l}\text { Bare } \\
\text { Land }\end{array}$ & $\begin{array}{l}\text { Total } \\
\text { Area }\end{array}$ \\
\hline \multirow{7}{*}{$\begin{array}{l}2000 \\
\left(\mathrm{~km}^{2}\right)\end{array}$} & Cropland & 815,279 & 1727 & 1187 & 100 & 19,235 & 3371 & 840,899 \\
\hline & Forest & 447 & 900,234 & 1280 & 65 & 2128 & 609 & 904,763 \\
\hline & Grassland & 1081 & 1770 & $1,477,895$ & 1259 & 1393 & 1506 & $1,484,904$ \\
\hline & Wetland & 421 & 20 & 462 & 444,594 & 657 & 2030 & 448,184 \\
\hline & Urban & 223 & 12 & 40 & 11 & 106,401 & 122 & 106,809 \\
\hline & Bare land & 784 & 53 & 194 & 862 & 749 & 138,227 & 140,870 \\
\hline & Total area & 818,235 & 903,816 & $1,481,058$ & 446,891 & 130,563 & 145,865 & $3,926,439$ \\
\hline
\end{tabular}

The correlation analysis indicated that AP had strong significant and positive effects on permanent and seasonal water bodies in 16 and 13 provinces, respectively (Figures 11 and 12). AMT had strong positive effects on both permanent and seasonal water bodies in southwest China. Reservoirs played an important role in the changes in both permanent and seasonal water bodies. In 30 and 29 provinces, reservoirs had significant positive effects on permanent and seasonal waters, respectively, indicating that reservoirs significantly contributed to the variations in water bodies in these provinces. In addition, cropland had significant negative effects on permanent and seasonal water bodies in 13 and six provinces, respectively, indicating that reclamation for cropland influenced the contraction of both permanent and seasonal water bodies in these provinces.

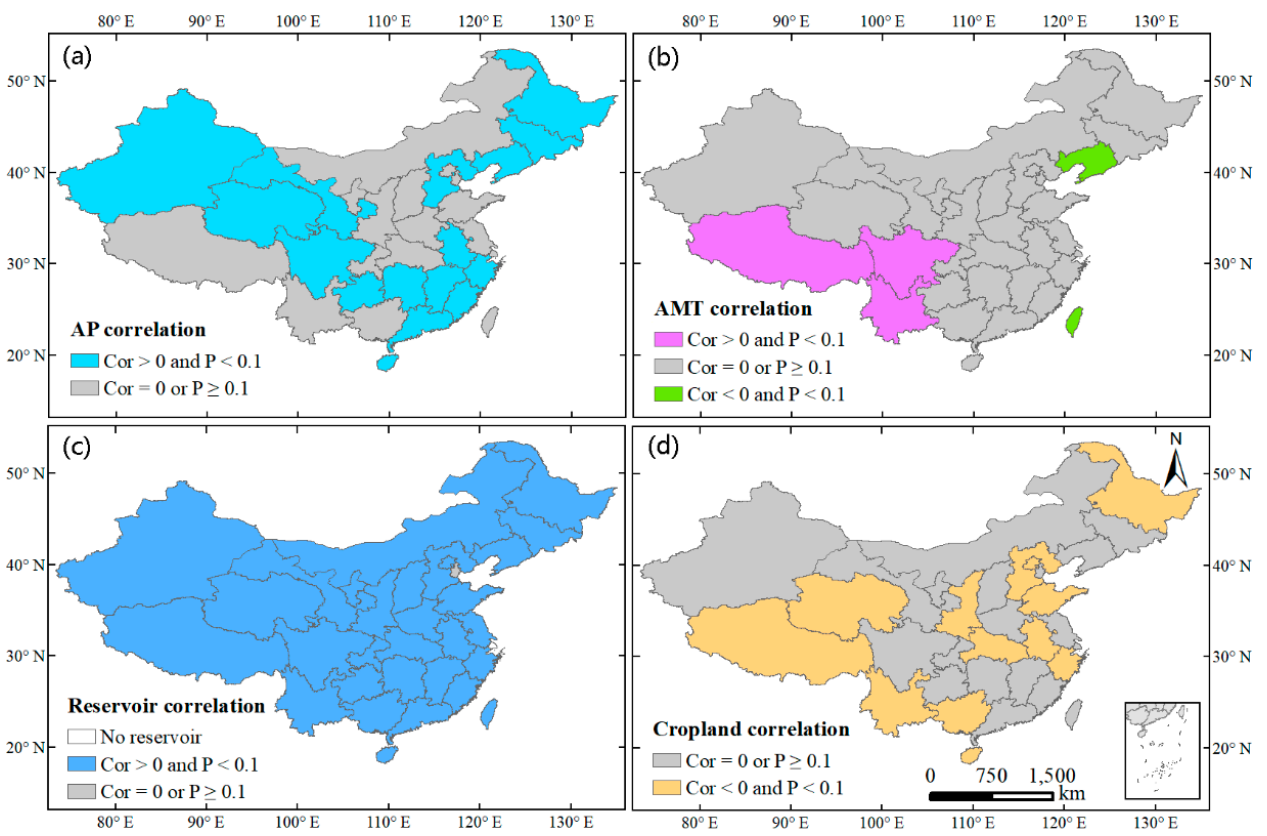

Figure 11. Correlation on the relationships between overall changes in permanent water area and (a) AP, (b) AMT, (c) reservoir and (d) cropland area at the provincial scale.

Furthermore, we quantified the relative contributions of the aforementioned climate and human factors to the changes in both permanent and seasonal water bodies by using a linear regression model and ANOVA (Figure 13). The results showed that reservoirs had strong explanatory power for the variations in both permanent and seasonal water bodies. On average, across all provinces in China, reservoirs explained $58.26 \%$ and $34.52 \%$ of the variation in permanent and seasonal water bodies, respectively. The top five provinces with respect to the power of reservoirs in explaining the variation in permanent water bodies were Chongqing (85.74\%), Hunan (82.06\%), Ningxia $(81.58 \%)$, Shaanxi $(80.79 \%)$ 
and Beijing $(80.86 \%)$, and the corresponding provinces for the variation in seasonal water bodies were Chongqing (90.11\%), Liaoning (76.71\%), Shandong (74.77\%), Sichuan (66.61\%) and Guangdong $(60.22 \%)$. The explanatory powers of other climate and human factors were obviously lower than those of reservoirs for the variations in both permanent and seasonal water bodies in most provinces across China. For example, in Shandong Province, reservoirs accounted for $42.88 \%$ of the variation in permanent water, and cropland, AP and AMT explained an additional $20.36 \%, 6.64 \%$ and $1.37 \%$, respectively, of the variation.

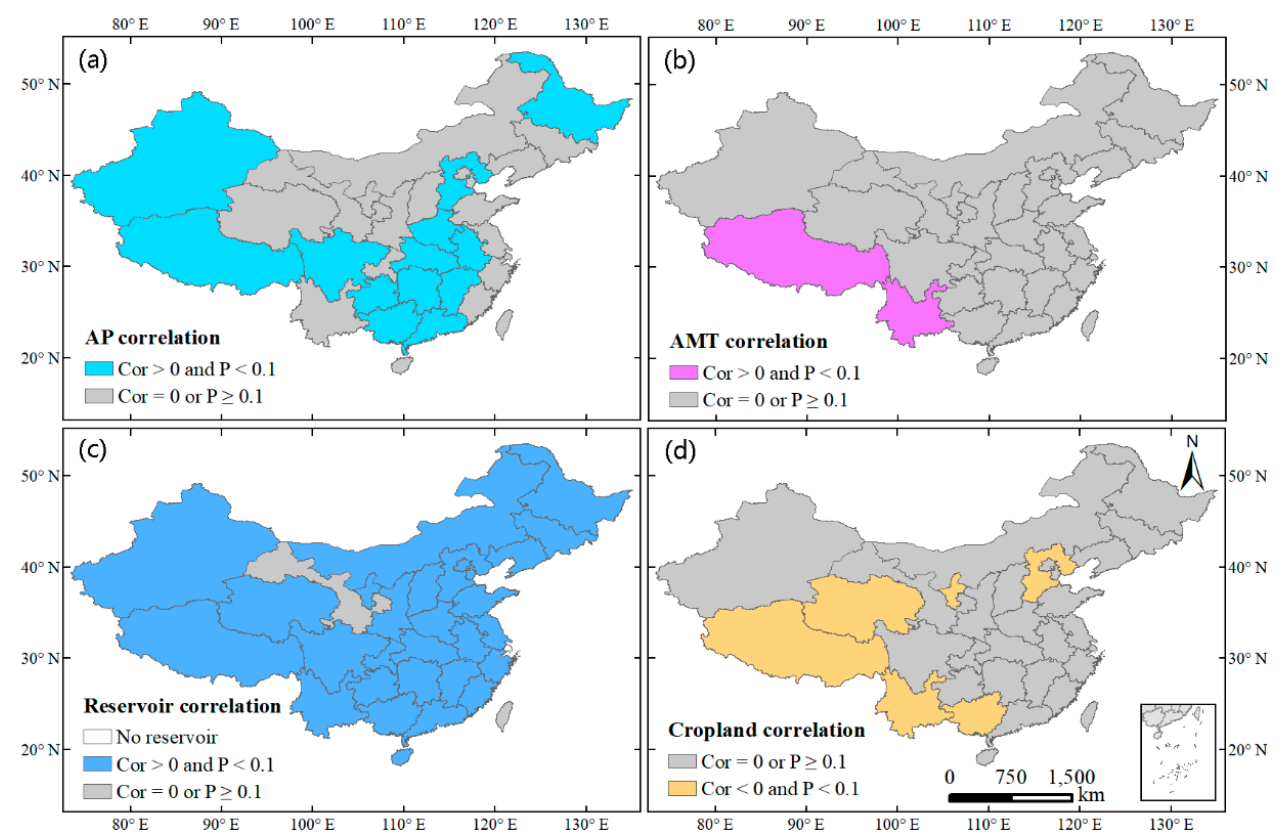

Figure 12. Correlation on the relationships between overall changes in seasonal water area and (a) AP, (b) AMT, (c) reservoir and (d) cropland area at the provincial scale.
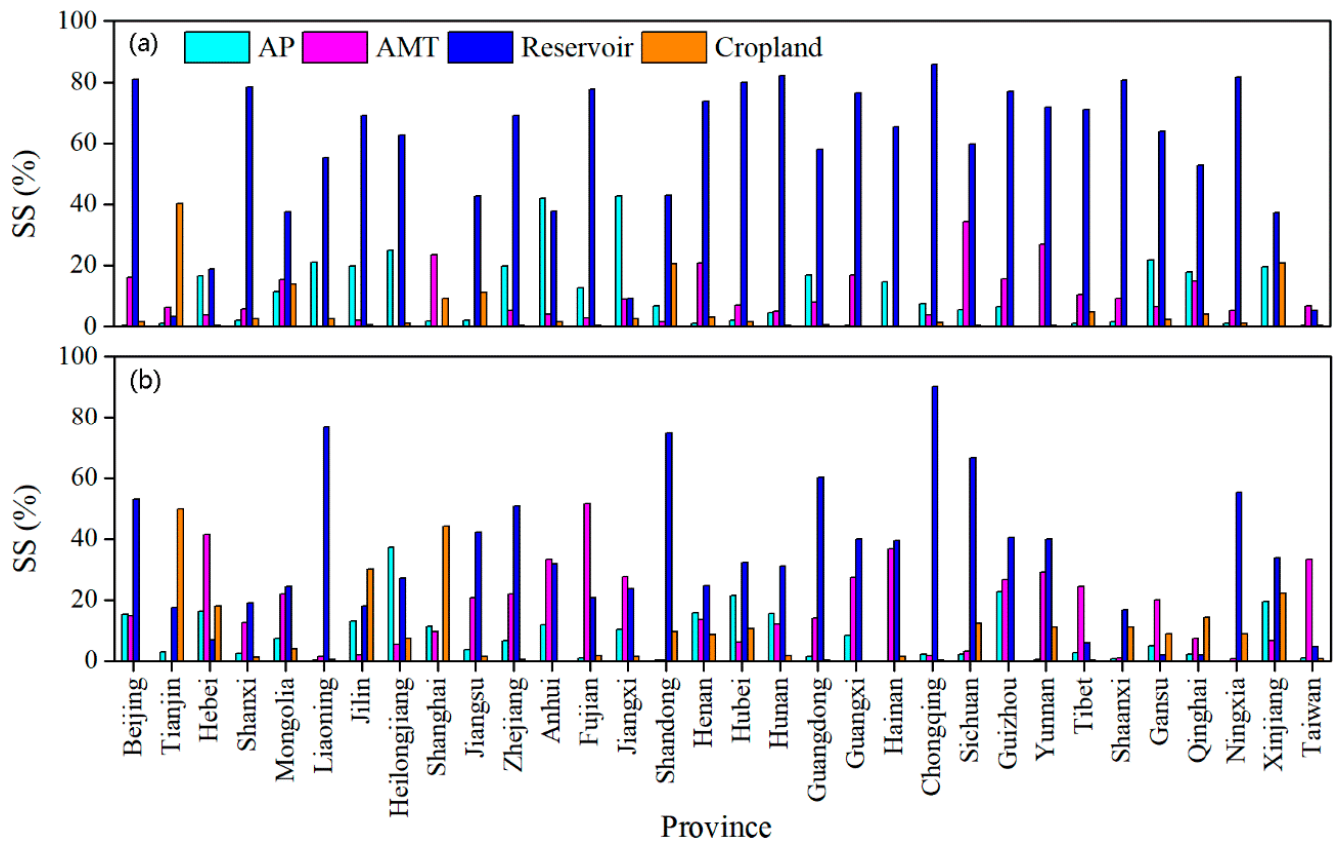

Figure 13. Proportion of surface water changes explained by climatic and human factors at the provincial scale. (a) Permanent water, and (b) seasonal water. SS is the proportion of variances explained by the variable. 


\section{Discussion}

\subsection{Spatiotemporal Changes in Different Types of Surface Water Bodies}

The percentage of China's surface water bodies represented by permanent and seasonal water bodies ranged from 57.00 to $66.43 \%$ and from 33.57 to $43.00 \%$, respectively, during 2000 to 2019, indicating that China had more permanent water bodies than seasonal ones. However, previous studies have reported far more seasonal surface water than permanent surface water [10]. This discrepancy can be attributed to study differences in the definition of surface water types, the number of Landsat images used, and mapping algorithms. For example, the GSWD data set was produced by using expert systems, visual analytics, and evidential reasoning techniques to address the challenges in separating water from other surfaces on the global scale, whereas previous studies mapped surface water based on the surface water frequency in a year $[49,64]$. In addition, the GSWD data set can provide much more reliable information about the major floods in southern China after 2000. For example, extensive flood events occurred in Jiangxi in 2010 and resulted in a large gain of both permanent and seasonal water bodies (Figure 14c). However, we must also recognize that the amount and data quality of Landsat imagery remain a concern. As Landsat satellite has a 16-day repeat cycle, it is challenging to capture some short-duration surface water events (e.g., fresh floods), because cloud-free satellite observation must coincide with these water events [2].
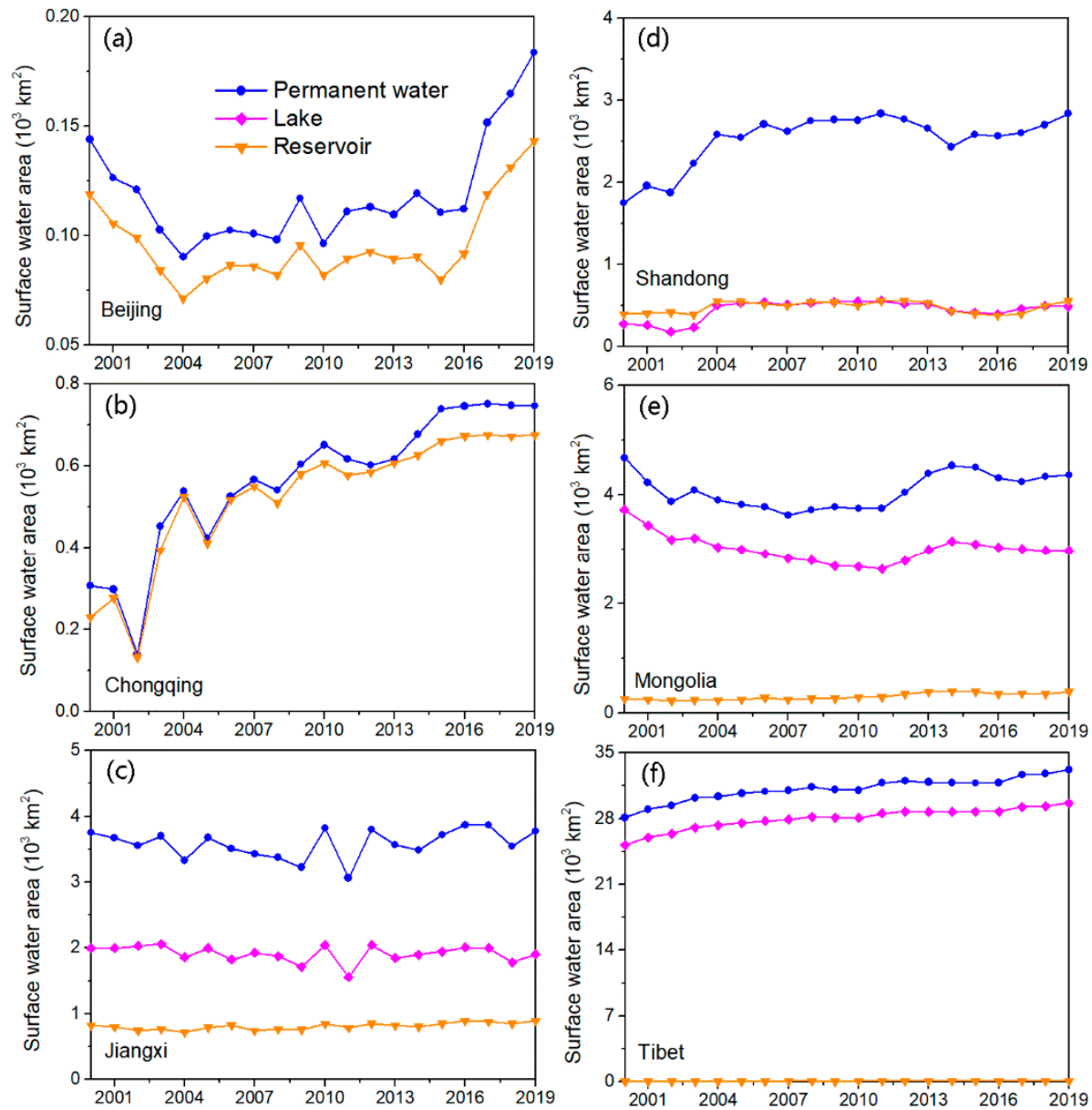

Figure 14. Areas of permanent water, lakes and reservoirs at the provincial scale. (a) Beijing, (b) Chongqing, (c) Jiangxi, (d) Shandong, (e) Mongolia, and (f) Tibet.

In our study, both permanent water and seasonal water showed clear uneven distributions at the provincial scale across China. Regarding permanent water, Tibet showed the largest expanding trend, mainly because of its large number of lakes and increased glacial 
meltwater [65-67], whereas Xinjiang exhibited the largest increasing trend for seasonal water bodies, which was mainly caused by increased AP and melting glaciers. Inner Mongolia, a typical arid and semiarid region that is very sensitive to climate change [68-70], exhibited the largest net loss of permanent water, which is consistent with findings in previous studies [31,64].

Lakes and reservoirs larger than $1 \mathrm{~km}^{2}$ were the main water resources in the country, especially among permanent water bodies. Lakes were mainly distributed on the Tibetan Plateau, in Northeast China and in the middle and lower reaches of the Yangtze River basin, and reservoirs were mainly located in Central and East China [39,44], consistent with the distribution of China's population (http://sedac.ciesin.columbia.edu/data/collection/ gpw-v4, accessed on 17 September 2020). The changes in both permanent and seasonal waters can be further decomposed into changes in lakes, reservoirs and other water bodies. In our study, the changes in lakes and reservoirs were in good agreement with the changes in permanent water bodies and seasonal bodies at the provincial scale. For example, the Tibetan Plateau region contains 51\% of the lake resources in China [42], and the expanding lakes contributed greatly to the increase in both permanent and seasonal waters in this region. Likewise, the shrinking lakes were consistent with the decrease in seasonal water bodies in the middle and lower reaches of the Yangtze River basin. In addition, reservoirs play an important role in surface water changes in some provinces. For example, the changes in the Miyun Reservoir, an important water source for Beijing, corresponded with the changes in both permanent and seasonal water bodies in Beijing, where the South-North Water Transfer project was implemented [71].

\subsection{Driving Forces of Changes in Surface Water}

Permanent and seasonal water bodies showed greatly different change trends, which were most likely driven by anthropogenic and climate factors [35,41]. Large hydrological projects (e.g., long-distance water transfer and dam construction) across China have been implemented to meet the water resource needs of an increasing population [72,73]. One example is the South-to-North Water Diversion (SNWD) project (the largest water transfer project in the world), which was launched in 2002 to transfer water from different reaches of the Yangtze River to North China through three canal and pipeline systems. The eastern route was designed to carry water from the lower reaches of the Yangtze River (i.e., Yangzhou city) through Jiangsu, Anhui, Shandong, Hebei and Tianjin starting in 2013. The middle route was designed to transfer water from the Danjiangkou Reservoir on the Han River (the largest tributary of the Yangtze River) through Hubei, Henan, Hebei, Beijing and Tianjin, starting in December 2014. The western route, which is planned to transfer water from the upper reaches of the Yangtze River to the upper reaches of the Yellow River, is still in the planning stage and has yet to transport water [71]. The SNWD project has been an important contributor to the changes in the water bodies in the provinces along its routes. For example, Beijing has gone through two phases of water diversion. The first phase was in 2008 to 2014, when major reservoirs in Hebei (e.g., Gangnan and Wangkuai Reservoirs) supplied $1.6 \mathrm{~km}^{3}$ of water to Beijing. The second phase was between December 2014 and December 2019, when the central SNWD route began operating, and a total of $5.2 \mathrm{~km}^{3}\left(\sim 1 \mathrm{~km}^{3} \mathrm{yr}^{-1}\right)$ of water reached Beijing, which caused the water area in Beijing to rise rapidly (Figure 14a). Shandong suffered from a severe drought in 2002, as shown by the very low permanent water area in 2002 (Figure 14d). The government implemented the Ecological Urgent Water Replenishing (EUWR) project to transfer water from the lower reaches of the Yangtze River to Nansihu Lake between 2002 and 2003 to sustain the lake, which was the reason for the rapidly expanding water area in this period [10]. The water area remained stable after the EUWR project from 2004 to 2014. With the completion of the first phase of the eastern route of the SNWD project, the water area has been further expanded in Shandong since 2014 (Figure 14d).

Dam and reservoir construction also affected the changes in both permanent and seasonal water bodies. For example, the TGD is the largest hydroelectric dam in the world 
and is located in western Hubei Province [4]. It has been in operation since 2003 and has contributed to the changes in both permanent and seasonal water bodies in nearby provinces [74]. For example, Chongqing is an upstream municipality of the TGD and has incrementally increased the surface water area from 2002 to 2015 (Figure 14b). These changes correspond well to the water level changes of the TGD reservoir, clearly indicating that the TGD increased the upstream surface water bodies. However, Jiangxi, which is a province downstream of the TGD, has shown a shrinking surface water area since 2003 (Figure 14c). These results indicate that the TGD reservoir can substantially change water resources in both its upstream and downstream regions [10]. Overall, with the new dam and reservoir construction, the original lands, such as forest, shrub, agricultural land and urban areas, became open water surface. Therefore, the number and capacity of reservoirs and their regulation rules can largely contribute to the changes in permanent and seasonal water bodies at the regional scale.

Climate change has been reported to have major impacts on surface water bodies. For example, the Tibetan Plateau, which is known as the "Water Tower of Asia" and "the Third Pole" of the world, has abundant lakes, rivers and glaciers with high elevations and sparse populations [67]. Both permanent and seasonal water bodies showed rapidly expanding trends on the Tibetan Plateau (Figure 7). According to our attribution analysis, the AMT on the Tibetan Plateau showed an obviously increasing trend (Figure 10), resulting in the expansion of surface water bodies by melting glaciers, snow and permafrost from high mountains $[20,33,75]$. Large lakes such as Nam Co and Selin Co showed clear expansions due to melting glaciers [76]. In general, precipitation on the Tibetan Plateau has remained largely stable over the last twenty years. In contrast, Xinjiang was the only province with a significant increase of both permanent and seasonal water bodies under arid and semiarid climates in northwest China (Figure 6), which were mainly caused by an increase in precipitation and glacier melting (Figures 11 and 12) [67]. These results indicate that on the Tibetan Plateau, glacier meltwater caused by a warming climate will increase in the near future but will likely decrease in the long term as the glacier shrinks [77].

The varied drivers of surface water variations in different provinces displayed the complexity of factors impacting water body dynamics in China. For Inner Mongolia, the coal mining and irrigation are the major reasons for the large loss of surface water bodies [10,64], as the annual coal production increased from 72 million tons in 2000 to 1066 million tons in 2012 when the total coal mining reached its peak and the irrigation area increased from $23,717 \mathrm{~km}^{2}$ in 2000 to $31,992 \mathrm{~km}^{2}$ in 2019, respectively. In Heilongjiang of Northeast China, the increased precipitation caused an elevated increase of surface water bodies, whereas in Guangxi province, additional new reservoirs had the largest contribution to the increased water bodies over years [10]. The annual mean temperature showed a strong negative effect on permanent water bodies in Liaoning province (Figure 11). In addition, human land use change activities also contribute to the increasing and/or decreasing trends of permanent and seasonal water bodies at different locations across China. For example, aquacultural change affects water body dynamics in China, especially in the coastal regions where climate and water resources are suitable for aquaculture [78]. Land reclamation (i.e., conversion of surface water bodies into agricultural/urban land) has greatly contributed to meeting the increasing demands for food and urban development, but has led to the loss or shrinking of water bodies, particularly in the Yangtze Plain of China [79]. Given the magnitude of the loss of cropland during the rapid urbanization (Table 4), urbanization might also promote surface water loss inside and outside urban areas, particularly in major city clusters in East China (e.g., Beijing-Tianjin-Hebei, Yangtze River Delta, Pearl River Delta, and the Middle Reach of the Yangtze River Basin) [45]. In our study, permanent and seasonal water bodies showed different trend throughout China, especially for 2010 to 2016 (Figure 5), mainly because of climate change and changes in human land use activities. For example, seasonal water had large decreases in 2012, which was related to severe drought in China. In general, seasonal water usually consists of the 
edge of permanent water, which would easily dry up due to the evaporation of the open water surface [49].

\section{Conclusions}

This study used multisource remote sensing data to explore the long-term changes in different surface water body types and the corresponding possible driving forces during 2000 to 2019 across China. The surface water bodies were classified into permanent and seasonal types based on the number of months that water was present. China was dominated by permanent water bodies, which were mainly distributed on the Tibetan Plateau and in the middle and lower reaches of the Yangtze River basin. Regarding the permanent water bodies, twenty-two provinces exhibited significant increasing trends, especially Tibet and Qinghai. However, for seasonal water bodies, only six provinces displayed significant increasing trends. These results indicated that the permanent and seasonal water bodies showed clear spatial heterogeneity. Moreover, lakes and reservoirs larger than $1 \mathrm{~km}^{2}$ were the main components of water bodies in China, especially among permanent water bodies. Apart from seasonal water bodies in reservoirs, lakes and reservoirs presented obvious increases in area over all of China. In general, geographically heterogeneous changes in both lake and reservoir areas were evident over the past two decades. The expanding lakes were mainly distributed on the Tibetan Plateau, whereas the shrinking lakes were distributed in Northeast China and in the middle and lower reaches of the Yangtze River basin. The expanding reservoirs with permanent and seasonal water bodies were mainly distributed in Hubei, Sichuan and Yunnan, whereas the shrinking reservoirs were mainly distributed in Shandong, Guangdong, and Hubei. Attribution analyses showed that human activities, such as the construction of dams and reservoirs, long-distance water transfer and land use change (land reclamation, cropland and urban expansion), have been the main factors leading to changes in both permanent and seasonal water bodies across China. However, climate change, especially temperature increases, has caused the expansion of different water body types on the sparsely populated Tibetan Plateau. This study represents an important contribution as it documents and provides insight into the types, locations and magnitudes of water changes that have taken place and their driving factors in China. The results presented here may provide scientific support to help government agencies develop sustainable water management strategies for the limited water resources in China.

Author Contributions: Conceptualization, B.Y. and B.C.; Formal analysis, B.Y. and Y.Z.; Funding acquisition, B.C. and B.Y.; Methodology, Y.Z. and C.W.; Writing-original draft, B.Y.; Writing—review and editing, C.W., Z.Z. and Y.W. All authors have read and agreed to the published version of the manuscript.

Funding: This work was funded by Key Project of National Natural Science Foundation of China (U1901212), Youth Program of Natural Science Foundation of China (42007413), and China Postdoctoral Science Foundation (2019M660516).

Data Availability Statement: Data is contained within the article.

Acknowledgments: We appreciate the "European Commission's Joint Research Centre (https:/ / global-surface-water.appspot.com, accessed on 17 August 2020)" for providing the surface water dataset. We appreciate the "China Meteorological Administration (http:/ / data.cma.cn, accessed on 20 August 2020)" and "Climatic Research Unit (http:/ / www.cru.uea.ac.uk/data, accessed on 20 August 2020)" for providing the climate-related data. We also appreciate the "National Energy Administration in China (http:/ / www.dam.com.cn, accessed on 27 August 2020)" for providing dam and reservoir data.

Conflicts of Interest: The authors declare no conflict of interest. 


\section{References}

1. Zou, Z.; Xiao, X.; Dong, J.; Qin, Y.; Doughty, R.B.; Menarguez, M.A.; Zhang, G.; Wang, J. Divergent trends of open-surface water body area in the contiguous United States from 1984 to 2016. Proc. Natl. Acad. Sci. USA 2018, 115, 3810-3815. [CrossRef] [PubMed]

2. Pekel, J.F.; Cottam, A.; Gorelick, N.; Belward, A.S. High-resolution mapping of global surface water and its long-term changes. Nature 2016, 540, 418-422. [CrossRef] [PubMed]

3. Vörösmarty, C.J.; McIntyre, P.B.; Gessner, M.O.; Dudgeon, D.; Prusevich, A.; Green, P.; Glidden, S.; Bunn, S.E.; Sullivan, C.A.; Liermann, C.R. Global threats to human water security and river biodiversity. Nature 2010, 467, 555-561. [CrossRef] [PubMed]

4. Wang, Y.; Ma, J.; Xiao, X.; Wang, X.; Dai, S.; Zhao, B. Long-term dynamic of poyang lake surface water: A mapping work based on the Google earth engine cloud platform. Remote Sens. 2019, 11, 313. [CrossRef]

5. Adrian, R.; O’Reilly, C.M.; Zagarese, H.; Baines, S.B.; Hessen, D.O.; Keller, W.; Livingstone, D.M.; Sommaruga, R.; Straile, D.; Van Donk, E. Lakes as sentinels of climate change. Limnol. Oceanogr. 2009, 54, 2283-2297. [CrossRef]

6. Jin, G.; Deng, X.; Hasan, S.S.; Zhao, C.; Gibson, J. Hydrological ecosystem services for integrated water resources management. Ecohydrology 2018, 361-386. [CrossRef]

7. Woolway, R.I.; Kraemer, B.M.; Lenters, J.D.; Merchant, C.J.; O’Reilly, C.M.; Sharma, S. Global lake responses to climate change. Nat. Rev. Earth Environ. 2020, 1, 388-403. [CrossRef]

8. Zhang, G.; Yao, T.; Xie, H.; Yang, K.; Zhu, L.; Shum, C.; Bolch, T.; Yi, S.; Allen, S.; Jiang, L. Response of Tibetan Plateau's lakes to climate changes: Trend, pattern, and mechanisms. Earth-Sci. Rev. 2020, 208, 103269. [CrossRef]

9. Smol, J.P.; Douglas, M.S. Crossing the final ecological threshold in high Arctic ponds. Proc. Natl. Acad. Sci. USA 2007, 104, 12395-12397. [CrossRef]

10. Wang, X.; Xiao, X.; Zou, Z.; Dong, J.; Qin, Y.; Doughty, R.B.; Menarguez, M.A.; Chen, B.; Wang, J.; Ye, H. Gainers and losers of surface and terrestrial water resources in China during 1989-2016. Nat. Commun. 2020, 11, 1-12. [CrossRef]

11. Salerno, F.; Gambelli, S.; Viviano, G.; Thakuri, S.; Guyennon, N.; D’Agata, C.; Diolaiuti, G.; Smiraglia, C.; Stefani, F.; Bocchiola, D.; et al. High alpine ponds shift upwards as average temperatures increase: A case study of the Ortles-Cevedale mountain group (southern Alps, Italy) over the last 50 years. Glob. Planet. Chang. 2014, 120, 81-91. [CrossRef]

12. Salerno, F.; Thakuri, S.; Guyennon, N.; Viviano, G.; Tartari, G. Glacier melting and precipitation trends detected by surface area changes in Himalayan ponds. Cryosphere 2016, 10, 1433-1448. [CrossRef]

13. Zhang, G.; Yao, T.; Xie, H.; Wang, W.; Yang, W. An inventory of glacial lakes in the Third Pole region and their changes in response to global warming. Glob. Planet. Chang. 2015, 131, 148-157. [CrossRef]

14. Mekonnen, M.M.; Hoekstra, A.Y. Four billion people facing severe water scarcity. Sci. Adv. 2016, 2, e1500323. [CrossRef]

15. Xu, L.; Chen, N.; Zhang, X.; Chen, Z. Spatiotemporal changes in China's terrestrial water storage from GRACE satellites and its possible drivers. J. Geophys. Res. Atmos. 2019, 124, 11976-11993. [CrossRef]

16. Thomas, B.F.; Famiglietti, J.S.; Landerer, F.W.; Wiese, D.N.; Molotch, N.P.; Argus, D.F. GRACE Groundwater Drought Index: Evaluation of California Central Valley groundwater drought. Remote Sens. Environ. 2017, 198, 384-392. [CrossRef]

17. Oki, T.; Kanae, S. Global hydrological cycles and world water resources. Science 2006, 313, 1068-1072. [CrossRef] [PubMed]

18. Jiang, Y. China's water scarcity. J. Environ. Manage. 2009, 90, 3185-3196. [CrossRef] [PubMed]

19. Jiang, Y. China's water security: Current status, emerging challenges and future prospects. Environ. Sci. Policy 2015, 54, 106-125. [CrossRef]

20. Mao, D.; Wang, Z.; Wu, J.; Wu, B.; Zeng, Y.; Song, K.; Yi, K.; Luo, L. China's wetlands loss to urban expansion. Land Degrad. Dev. 2018, 29, 2644-2657. [CrossRef]

21. Ma, T.; Sun, S.; Fu, G.; Hall, J.W.; Ni, Y.; He, L.; Yi, J.; Zhao, N.; Du, Y.; Pei, T. Pollution exacerbates China's water scarcity and its regional inequality. Nat. Commun. 2020, 11, 1-9. [CrossRef]

22. Mao, D.; Wang, Z.; Yang, H.; Li, H.; Thompson, J.R.; Li, L.; Song, K.; Chen, B.; Gao, H.; Wu, J. Impacts of climate change on Tibetan lakes: Patterns and processes. Remote Sens. 2018, 10, 358. [CrossRef]

23. Zong, Y.; Chen, X. The 1998 flood on the Yangtze, China. Nat. Hazards 2000, 22, 165-184. [CrossRef]

24. Lin, W.; Wen, C.; Wen, Z.; Gang, H. Drought in Southwest China: A review. Atmos. Ocean. Sci. Lett. 2015, 8, 339-344.

25. Chen, H.; Sun, J. Characterizing present and future drought changes over eastern China. Int. J. Climatol. 2017, 37, 138-156. [CrossRef]

26. Zhang, Y.; Shi, K.; Zhou, Y.; Liu, X.; Qin, B. Monitoring the river plume induced by heavy rainfall events in large, shallow, Lake Taihu using MODIS $250 \mathrm{~m}$ imagery. Remote Sens. Environ. 2016, 173, 109-121. [CrossRef]

27. Lu, S.; Jia, L.; Zhang, L.; Wei, Y.; Baig, M.H.A.; Zhai, Z.; Meng, J.; Li, X.; Zhang, G. Lake water surface mapping in the Tibetan Plateau using the MODIS MOD09Q1 product. Remote Sens. Lett. 2017, 8, 224-233. [CrossRef]

28. Li, L.; Vrieling, A.; Skidmore, A.; Wang, T.; Turak, E. Monitoring the dynamics of surface water fraction from MODIS time series in a Mediterranean environment. Int. J. Appl. Earth Obs. Geoinf. 2018, 66, 135-145. [CrossRef]

29. Khandelwal, A.; Karpatne, A.; Marlier, M.E.; Kim, J.; Lettenmaier, D.P.; Kumar, V. An approach for global monitoring of surface water extent variations in reservoirs using MODIS data. Remote Sens. Environ. 2017, 202, 113-128. [CrossRef]

30. Rao, P.; Jiang, W.; Hou, Y.; Chen, Z.; Jia, K. Dynamic change analysis of surface water in the Yangtze River Basin based on MODIS products. Remote Sens. 2018, 10, 1025. [CrossRef] 
31. Tao, S.; Fang, J.; Zhao, X.; Zhao, S.; Shen, H.; Hu, H.; Tang, Z.; Wang, Z.; Guo, Q. Rapid loss of lakes on the Mongolian Plateau. Proc. Natl. Acad. Sci. USA 2015, 112, 2281-2286. [CrossRef] [PubMed]

32. Xia, H.; Zhao, J.; Qin, Y.; Yang, J.; Cui, Y.; Song, H.; Ma, L.; Jin, N.; Meng, Q. Changes in water surface area during $1989-2017$ in the Huai River Basin using Landsat data and Google earth engine. Remote Sens. 2019, 11, 1824. [CrossRef]

33. Qiao, B.; Zhu, L.; Yang, R. Temporal-spatial differences in lake water storage changes and their links to climate change throughout the Tibetan Plateau. Remote Sens. Environ. 2019, 222, 232-243. [CrossRef]

34. Deng, Y.; Jiang, W.; Tang, Z.; Ling, Z.; Wu, Z. Long-term changes of open-surface water bodies in the Yangtze River basin based on the Google Earth Engine cloud platform. Remote Sens. 2019, 11, 2213. [CrossRef]

35. Zhang, G.; Yao, T.; Chen, W.; Zheng, G.; Shum, C.; Yang, K.; Piao, S.; Sheng, Y.; Yi, S.; Li, J. Regional differences of lake evolution across China during 1960s-2015 and its natural and anthropogenic causes. Remote Sens. Environ. 2019, 221, 386-404. [CrossRef]

36. Feng, S.; Liu, S.; Huang, Z.; Jing, L.; Zhao, M.; Peng, X.; Yan, W.; Wu, Y.; Lv, Y.; Smith, A.R. Inland water bodies in China: Features discovered in the long-term satellite data. Proc. Natl. Acad. Sci. USA 2019, 116, 25491-25496. [CrossRef]

37. Lehner, B.; Döll, P. Development and validation of a global database of lakes, reservoirs and wetlands. J. Hydrol. 2004, $296,1-22$. [CrossRef]

38. Messager, M.L.; Lehner, B.; Grill, G.; Nedeva, I.; Schmitt, O. Estimating the volume and age of water stored in global lakes using a geo-statistical approach. Nat. Commun. 2016, 7, 1-11. [CrossRef]

39. Lehner, B.; Liermann, C.R.; Revenga, C.; Vörösmarty, C.; Fekete, B.; Crouzet, P.; Döll, P.; Endejan, M.; Frenken, K.; Magome, J. High-resolution mapping of the world's reservoirs and dams for sustainable river-flow management. Front. Ecol. Environ. 2011, 9 , 494-502. [CrossRef]

40. Wang, S.; Dou, H. Chinese Lakes Inventory; Science Press: Beijing, China, 1998.

41. Ma, R.; Duan, H.; Hu, C.; Feng, X.; Li, A.; Ju, W.; Jiang, J.; Yang, G. A half-century of changes in China's lakes: Global warming or human influence? Geophys. Res. Lett. 2010, 37, L24106. [CrossRef]

42. Tao, S.; Fang, J.; Ma, S.; Cai, Q.; Xiong, X.; Tian, D.; Zhao, X.; Fang, L.; Zhang, H.; Zhu, J. Changes in China's lakes: Climate and human impacts. Natl. Sci. Rev. 2020, 7, 132-140. [CrossRef]

43. Zhu, J.; Song, C.; Wang, J.; Ke, L. China's inland water dynamics: The significance of water body types. Proc. Natl. Acad. Sci. USA 2020, 117, 13876-13878. [CrossRef]

44. Grill, G.; Lehner, B.; Thieme, M.; Geenen, B.; Tickner, D.; Antonelli, F.; Babu, S.; Borrelli, P.; Cheng, L.; Crochetiere, H. Mapping the world's free-flowing rivers. Nature 2019, 569, 215-221. [CrossRef]

45. Xu, W.; Fan, X.; Ma, J.; Pimm, S.L.; Kong, L.; Zeng, Y.; Li, X.; Xiao, Y.; Zheng, H.; Liu, J. Hidden loss of wetlands in China. Curr. Biol. 2019, 29, 3065-3071.e3062. [CrossRef] [PubMed]

46. Wang, L.; Henderson, M.; Liu, B.; Shen, X.; Chen, X.; Lian, L.; Zhou, D. Maximum and minimum soil surface temperature trends over China, 1965-2014. J. Geophys. Res. Atmos. 2018, 123, 2004-2016. [CrossRef]

47. Gorelick, N.; Hancher, M.; Dixon, M.; Ilyushchenko, S.; Thau, D.; Moore, R. Google Earth Engine: Planetary-scale geospatial analysis for everyone. Remote Sens. Environ. 2017, 202, 18-27. [CrossRef]

48. Campos, J.C.; Sillero, N.; Brito, J.C. Normalized difference water indexes have dissimilar performances in detecting seasonal and permanent water in the Sahara-Sahel transition zone. J. Hydrol. 2012, 464, 438-446. [CrossRef]

49. Zou, Z.; Dong, J.; Menarguez, M.A.; Xiao, X.; Qin, Y.; Doughty, R.B.; Hooker, K.V.; Hambright, K.D. Continued decrease of open surface water body area in Oklahoma during 1984-2015. Sci. Total Environ. 2017, 595, 451-460. [CrossRef] [PubMed]

50. Zhang, G.; Chen, W.; Zheng, G.; Xie, H.; Shum, C. Are China's water bodies (lakes) underestimated? Proc. Natl. Acad. Sci. USA 2020, 117, 6308-6309. [CrossRef] [PubMed]

51. Zeng, Y.; Yang, X.; Fang, N.; Shi, Z. Large-scale afforestation significantly increases permanent surface water in China's vegetation restoration regions. Agric. For. Meteorol. 2020, 290, 108001. [CrossRef]

52. Hutchinson, M.F. ANUSPLIN Version 4. 2 User Guide. Canberra: The Australia National University, Center for Resource and Environment Studies. 2004. Available online: http:/ / cres.anu.edu.au/outputs/anusplin.php (accessed on 20 August 2020).

53. Hutchinson, M.F. Interpolation of rainfall data with thin plate smoothing splines. Part I: Two dimensional smoothing of data with short range correlation. J. Geo-Graph. Inf. Decis. Anal. 1998, 2, 139-151.

54. Harris, I.; Jones, P.D.; Osborn, T.J.; Lister, D.H. Updated high-resolution grids of monthly climatic observations-The CRU TS3. 10 Dataset. Int. J. Climatol. 2014, 34, 623-642. [CrossRef]

55. New, M.; Hulme, M.; Jones, P. Representing Twentieth-Century Space-Time Climate Variability. Part II: Development of 1901-96 Monthly Grids of Terrestrial Surface Climate. J. Clim. 2000, 13, 2217-2238. [CrossRef]

56. Ma, R.; Yang, G.; Duan, H.; Jiang, J.; Wang, S.; Feng, X.; Li, A.; Kong, F.; Xue, B.; Wu, J. China's lakes at present: Number, area and spatial distribution. Sci. China Earth Sci. 2011, 54, 283-289. [CrossRef]

57. Mann, H.B. Nonparametric tests against trend. Econometrica 1945, 13, 245-259. [CrossRef]

58. Kendall, M.G. Rank Correlation Methods, 4th ed.; Charles Griffin: London, UK, 1975.

59. Theil, H. A rank-invariant method of linear and polynomial regression analysis I, II and III. In Proceedings of the Section Sciences, Koninklijke Academie van Wetenschappen te, Amsterdam, The Netherlands, 25 February 1950; pp. 386-392.

60. Sen, P.K. Estimates of the regression coefficient based on Kendall's tau. J. Am. Stat. Assoc. 1968, 63, 1379-1389. [CrossRef]

61. Lavagnini, I.; Badocco, D.; Pastore, P.; Magno, F. Theil-Sen nonparametric regression technique on univariate calibration, inverse regression and detection limits. Talanta 2011, 87, 180-188. [CrossRef] [PubMed] 
62. Li, F.; Zhang, G.; Xu, Y.J. Spatiotemporal variability of climate and streamflow in the Songhua River Basin, northeast China. J. Hydrol. 2014, 514, 53-64. [CrossRef]

63. Team, R.C. R: A Language and Environment for Statistical Computing; R Foundation for Statistical Computing: Vienna, Austria, 2019

64. Zhou, Y.; Dong, J.; Xiao, X.; Liu, R.; Zou, Z.; Zhao, G.; Ge, Q. Continuous monitoring of lake dynamics on the Mongolian Plateau using all available Landsat imagery and Google Earth Engine. Sci. Total Environ. 2019, 689, 366-380. [CrossRef]

65. Yao, T.; Thompson, L.; Yang, W.; Yu, W.; Gao, Y.; Guo, X.; Yang, X.; Duan, K.; Zhao, H.; Xu, B. Different glacier status with atmospheric circulations in Tibetan Plateau and surroundings. Nat. Clim. Chang. 2012, 2, 663-667. [CrossRef]

66. Song, C.; Huang, B.; Ke, L. Modeling and analysis of lake water storage changes on the Tibetan Plateau using multi-mission satellite data. Remote Sens. Environ. 2013, 135, 25-35. [CrossRef]

67. Gao, J.; Yao, T.; Masson-Delmotte, V.; Steen-Larsen, H.C.; Wang, W. Collapsing glaciers threaten Asia's water supplies. Nature 2019, 565, 19-21. [CrossRef] [PubMed]

68. Gao, H.; Ryan, M.C.; Li, C.; Sun, B. Understanding the role of groundwater in a remote transboundary lake (Hulun Lake, China). Water 2017, 9, 363. [CrossRef]

69. O'Reilly, C.M.; Sharma, S.; Gray, D.K.; Hampton, S.E.; Read, J.S.; Rowley, R.J.; Schneider, P.; Lenters, J.D.; McIntyre, P.B.; Kraemer, B.M. Rapid and highly variable warming of lake surface waters around the globe. Geophys. Res. Lett. 2015, 42, 10-773. [CrossRef]

70. Chen, J.; John, R.; Zhang, Y.; Shao, C.; Brown, D.G.; Batkhishig, O.; Amarjargal, A.; Ouyang, Z.; Dong, G.; Wang, D. Divergences of two coupled human and natural systems on the Mongolian Plateau. Bioscience 2015, 65, 559-570. [CrossRef]

71. Long, D.; Yang, W.; Scanlon, B.R.; Zhao, J.; Liu, D.; Burek, P.; Pan, Y.; You, L.; Wada, Y. South-to-North Water Diversion stabilizing Beijing's groundwater levels. Nat. Commun. 2020, 11, 1-10. [CrossRef]

72. Feng, L.; Han, X.; Hu, C.; Chen, X. Four decades of wetland changes of the largest freshwater lake in China: Possible linkage to the Three Gorges Dam? Remote Sens. Environ. 2016, 176, 43-55. [CrossRef]

73. Han, X.; Feng, L.; Hu, C.; Chen, X. Wetland changes of China's largest freshwater lake and their linkage with the Three Gorges Dam. Remote Sens. Environ. 2018, 204, 799-811. [CrossRef]

74. Wu, J.; Huang, J.; Han, X.; Gao, X.; He, F.; Jiang, M.; Jiang, Z.; Primack, R.B.; Shen, Z. The three gorges dam: An ecological perspective. Front. Ecol. Environ. 2004, 2, 241-248. [CrossRef]

75. Zhang, G.; Li, J.; Zheng, G. Lake-area mapping in the Tibetan Plateau: An evaluation of data and methods. Int. J. Remote Sens. 2017, 38, 742-772. [CrossRef]

76. Lu, A.X. Study on the fluctuations of typical glaciers and lakes in the Tibetan Plateau using remote sensing. J. Glaciol. Geocryol. 2005, 27, 783-792.

77. Solomon, S.; Plattner, G.K.; Knutti, R.; Friedlingstein, P. Irreversible climate change due to carbon dioxide emissions. Proc. Natl. Acad. Sci. USA 2009, 106, 1704-1709. [CrossRef]

78. Ren, C.; Wang, Z.; Zhang, Y.; Zhang, B.; Song, K. Rapid expansion of coastal aquaculture ponds in China from Landsat observations during 1984-2016. Int. J. Appl. Earth Obs. 2019, 82, 101902. [CrossRef]

79. Hou, X.; Feng, L.; Tang, J.; Song, X.P.; Bryan, B.A. Anthropogenic transformation of Yangtze Plain freshwater lakes: Patterns, drivers and impacts. Remote Sens. Environ. 2020, 248, 111998. [CrossRef] 